Adv Pharmacol. 2012 ; 65: 361-398. doi:10.1016/B978-0-12-397927-8.00012-9.

\title{
Chemoprevention of Melanoma
}

\author{
SubbaRao V. Madhunapantula ${ }^{1}$ and Gavin P. Robertson $2,3,4,5,6,7,8$ \\ ${ }^{1}$ Jagadguru Sri Shivarathreeshwara Medical College, Jagadguru Sri Shivarathreeshwara \\ University, Mysore, Karnataka 570 015, India \\ 2Department of Pharmacology, The Pennsylvania State University College of Medicine, Hershey, \\ PA 17033 \\ ${ }^{3}$ Department of Pathology, The Pennsylvania State University College of Medicine, Hershey, PA \\ 17033 \\ ${ }^{4}$ Department of Dermatology, The Pennsylvania State University College of Medicine, Hershey, \\ PA 17033 \\ ${ }^{5}$ Department of Surgery, The Pennsylvania State University College of Medicine, Hershey, PA \\ 17033 \\ ${ }^{6}$ Penn State Melanoma Center, The Pennsylvania State University College of Medicine, Hershey, \\ PA 17033 \\ ${ }^{7}$ Penn State Melanoma Therapeutics Program, The Pennsylvania State University College of \\ Medicine, Hershey, PA 17033 \\ ${ }^{8}$ The Foreman Foundation for Melanoma Research, The Pennsylvania State University College of \\ Medicine, Hershey, PA 17033
}

\section{Abstract}

Despite advances in drug discovery programs and molecular approaches for identifying the drug targets, incidence and mortality rates due to melanoma continues to rise at an alarming rate. Existing preventive strategies generally involve mole screening followed by surgical removal of the benign nevi and abnormal moles. However, due to lack of effective programs for screening and disease recurrence after surgical resection there is a need for better chemopreventive agents. Although sunscreens have been used extensively for protecting from UV-induced skin cancer, results of correlative population based studies are controversial, requiring further authentication to conclusively confirm the chemoprotective efficacy of sunscreens. Certain studies suggest increased skin-cancer rates in sunscreen users. Therefore, effective chemopreventive agents for preventing melanoma are urgently required. This book-chapter, reviews the current understanding regarding melanoma chemoprevention and the various strategies used to accomplish this objective.

\section{INTRODUCTION}

Chemoprevention is a strategy that was first proposed by Sporn, Dunlop, Newton, and Smith (1). It referred to the use of natural or synthetic agents to reverse, suppress, or prevent molecular or histologic premalignant lesions from progressing to invasive cancer (1). The original definition also included treating patients who had undergone successful primary cancer treatment but were at increased risk of developing a second primary cancer $(1,2)$.

Request for reprints: Gavin P. Robertson, Department of Pharmacology, The Pennsylvania State University College of Medicine, R130, 500 University Drive, Hershey, PA 17033. Phone: (717) 531-8098; Fax: (717) 531-5013; gprobertson@ psu.edu. 
More recently, cancer delay has been emphasized as yet another goal of chemoprevention $(3,4)$. Chemopreventive agents that delay the onset of melanoma are extremely important as even small changes in the early melanocytic lesion size can significantly alter the 5-year survival rate $(5,6)$. For example a change in the Breslow depth of $4 \mathrm{~mm}$ compared to 0.7 $\mathrm{mm}$ could decrease the 5 -year survival by $40 \%(5,6)$. In breast and other cancers, chemoprevention has proven successful (7). Tamoxifen, the first Food and Drug Administration (FDA)-approved chemopreventive agent, has been used effectively to reduce breast cancers (8) (http://www.fda.gov/NewsEvents/Testimony/ucm115118.htm). Similarly the FDA approved topical diclofenac and imiquimod were proven effective for actinic keratoses treatment (9)

Chemoprevention of melanoma is based on the principle that melanoma is a progressive disease, and various molecular events and pathways associated with different stages of the disease can be targeted using synthetic or naturally occurring chemical compounds (10). However, chemoprevention of melanoma remains an underdeveloped area. One of the reasons for this under-exploration is the logistical and procedural difficulties associated with testing of chemopreventive agents in clinical trials. Even though $\sim 30 \%$ melanomas are known to be caused by exposure to UV radiation, risk factors responsible for about $60 \%$ melanomas are unknown (11-14). Furthermore, the molecular basis for UV-mediated transformation of melanocytes to melanomas is also not fully understood (15-17). Moreover results of recent trials evaluating whether limiting or blocking sun exposure to reduce melanoma incidence and mortality rates are confusing and not encouraging (18-21). Therefore chemoprevention of melanoma remains a challenge to the scientific community. Recent studies have focused on identifying the molecular pathways triggering the transformation of melanocytes to melanomas when exposed to UV light, as well as genetic and non-genetic risk factors that could be targeted for chemoprevention (10, 22-26). For example, ras-signaling can be used as a chemoprevention target in UV-induced melanomas $(27,28)$.

Broadly, three categories of melanoma chemopreventive agents exist $(6,29)$ (Figure 1). The first category prevents the occurrence of melanoma in healthy individuals, whereas, the second and third categories prevent melanoma development in melanoma patients $(6,29)$ (Figure 1). Secondary chemopreventive agents would prevent pre-malignant melanomas from developing into malignant melanomas $(6,29)$ (Figure 1). Tertiary chemopreventive agents would prevent melanomas to reoccur after getting treated for melanomas $(6,29)$ (Figure 1).

An ideal chemopreventive agent should inhibit (a) oncogenic kinases inducing the transformation of melanocytes, and (b) trigger apoptosis in damaged melanocytes $(10,30)$. In addition, chemopreventive agents should also induce DNA repair pathways so that the UV-induced damage could be alleviated thereby preventing transformation (31-33). Therefore, chemoprevention strategies should consider following key aspects while developing a particular compound for preventing melanomas: (a) molecular basis of melanoma genesis and tumor progression; (b) reasons for the failure of existing agents; (c) selection of appropriate in vitro and in vivo models representing different stages of tumor progression for testing the identified agents; and (d) better methods of drug delivery, which helps to reduce toxicity as well as release the preventive agent at the site of action $(34,35)$

\section{Melanoma models for studying the efficacy of chemopreventive agents}

There is an urgent need to develop models for studying the efficacy of chemopreventive agents for melanoma. Since, there is not much information available about the molecular or histological markers of the carcinogenic processes to be used as endpoints and prognosticas well as drug efficacy predictive indicators, development of potent chemopreventive 
agents for inhibiting melanomas has been hampered (36). Furthermore, testing the efficacy of developed chemopreventive agents in prevention studies in humans require long periods and involves many ethical, financial as well as experimental difficulties $(34,35,37)$. Therefore there is an urgent need to develop clinical research models to evaluate candidate chemopreventive agents for inhibiting melanoma development. The in vitro and in vivo animal models that are in wide usage for assessing chemoprevention include (a) laboratory generated skin reconstructs with and without melanoma tumor nodules (38-40); (b) use of human skins to test the drug permeability and safety; (c) xenografted melanoma tumor models combining with topical/oral administration of chemopreventive agents (38-40); and (d) use of spontaneous melanoma models $(41,42)$ (Figure 2). Other models that have been developed to test chemopreventive agents include (a) transgenic hepatocyte growth factor (HGF)-scatter factor (SF) mouse models (43); (b) transgenic mouse SV40 T antigen (44); (c) spontaneous and UV induced xiphophorus fish model where melanoma progression from nevus to melanoma has be studied $(45,46)$ (Figure 2). Appropriate models also have to assess the suitability of administration of the particular agents, which can be a challenge for certain of these models.

\section{Chemopreventive agents that have been tested for preventing melanomas}

Statins-Results of recent preclinical as well as Phase-I and Phase-II clinical trials and unanticipated secondary clinical observations from cardiovascular disease trials have led to enthusiasm regarding the use of statins for melanoma prevention (47-50). Statins are antiproliferative, proapoptotic, angiostatic, anti-invasive and immunomodulatory compounds known to inhibit Ras proteins (49). Mechanistically statins inhibit key steps in the mevalonate pathway to decrease protein prenylation $(49,51)$. Lack of this posttranslational modification of Ras and many other proteins impedes function, resulting in the prevention of melanoma cell proliferation and oncogenicity $(49,51)$. A recent study showed inhibition of geranylgeranylation of RhoC and other small G-proteins by atrovastatin, which reverted the metastatic phenotype in human melanomas expressing this protein (52) (Figure 3 ). While preclinical findings support the chemopreventive ability of statins for melanoma prevention, epidemiological data are yet to confirm this observation $(6,48,53,54)$. A metaanalysis of randomized controlled trials of statins in cardiovascular disease found no statistically significant differences between statin and observation groups with respect to melanoma incidence $(48,55)$. Despite these observations, the usage of statins for melanoma chemoprevention continues, as the safety-profile of these compounds is very good $(49,56)$. Moreover, some of the published meta-analysis reports failed to include the results of most recent clinical trials, which showed positive association between statins use and melanoma prevention $(48,57)$. Therefore, use of statins for preventing melanoma needs further evaluation in large, multi-centric trials. The Southwest Oncology Group (SWOG) has proposed a phase IIB chemoprevention study of statins versus placebo in a population of patients who have been treated for early-stage melanomas or the presence of clinically atypical nevi (34). This phase IIB trial will involve dermatologists, medical and surgical oncologists that will undertake prospective evaluation of biological markers in both blood and biopsied nevi (34). Results of this clinical trial are expected to yield enough data to determine whether statins have a role in melanoma prevention, or the reported observations are just a chance by luck.

Curcumins-Curcumin, chemically 1,7-Bis-[4-hydroxy-3-methoxyphenyl]-1,6heptadiene-3,5-dione; also known as diferuloylmethane, is a commonly used spice derived from Curcuma longa (turmeric) $(58,59)$ (Figure 3). Although, the clinical efficacy of this yellow pigment is yet to be confirmed, in vitro observations using cultured cells and in vivo studies in xenografted and carcinogen induced animal models suggest it may perform a chemopreventive role in melanomas (60-64). Curcumin and its derivatives act by inhibiting 
key enzymes involved in melanoma tumor development $(64,65)$. For example, curcumin inhibits the xanthine oxidase, tyrosine kinase, cyclooxygenase (COX) and lipo-oxygenase (LOX) enzymes thereby exerting anti-oxidant effects $(58,59)$. Curcumin also inhibited cell survival by targeting NF-kB and XIAP only in melanoma cells but not in melanocytes (58, $59,66,67)$. Topical application of curcumin inhibited UVB-induced NF-kB activation in cultured keratinocytes and TPA-induced tumor formation in mice $(68,69)$. Furthermore, curcumin treatment reduced lung metastasis of B16F-10 melanoma cells in experimental models of metastasis and increased the lifespan of animals $(70,71)$. Mechanistically, curcumin treatment inhibited matrix metalloproteinases to reduce melanoma cell invasion and metastasis (72).

Curcumin protects from UVA and UVB induced skin damage by triggering DNA repair mechanisms (73). Although UVB is primarily responsible for skin cancers initiation and progression, recent studies have also found the involvement of UVA in melanoma and nonmelanoma skin cancer development (74). Despite its anti-cancer activity as well as safety and tolerability profiles, not many clinical trials have been conducted to study the efficacy of curcumin for inhibiting melanomas $(75,76)$. Some of the practical concerns associated with curcumin use for melanoma prevention include (a) its nature to stain skin; (b) poor absorption; and (c) rapid metabolism which limits its availability (76). However various semi-synthetic derivatives and nano-formulations have been developed that can overcome these limitations (77). A recent study also demonstrated augmentation of tumoricidal properties of curcumin when coupled with a cancer cell-specific antibody (78). This study evaluated the efficacy of curcumin coupled to a melanoma surface antigen recognizing Muc18 antibody, through a cleavable arm, for preventing B16F-10 melanoma tumor growth in mice (78). The Curcumin-Muc18 antibody complex was found 230 fold more effective at inhibiting melanoma cell metastasis in mice than the unconjugated control (78). Although these preclinical trials are encouraging, the clinical trials data is not available yet, hence, warranting further studies to determine the safety, efficacy and feasibility of translating these preclinical mice studies in to efficacy for humans.

Resveratrol-Chemically known as 3,5,4' -trihydroxy-trans-stilbene, resveratrol is a polyphenolic phytoalexin isolated from grapes, mulberries and peanuts (79) (Figure 3). Resveratrol is a good antioxidant (80). Due to it's anti-inflammatory and anti-proliferative properties, resveratrol effectively inhibits initiation, progression and metastasis of several cancers including those of the breast, prostate and skin (80). For example, topical resveratrol has been demonstrated to protect skin from UV induced tumor growth by inhibiting COX-2 as well as mTORC2 component rictor and hydrogen peroxide formation $(81,82)$.

Resveratrol can also protect cells by preventing radiation induced DNA damage $(83,84)$. Studies have shown that this natural product scavenges free radicals and inhibit the activation of polyhydroxy aromatic hydrocarbon carcinogens (84-86). Many in vitro and in vivo studies using animal models show that resveratrol (a) arrests cells in G0/G1 phase of the cell cycle; (b) inhibits Pi3K-Akt signaling; (c) down-regulates NF-kB activation by blocking IKK; and (d) upregulates Egr-1, a known inhibitor of Cdk2 (80, 85). In addition, resveratrol can also inhibit survivin, TGF-beta signaling and sensitize cells to TRAIL (83, 87). Collectively, these combined effects mediated by resveratrol, trigger apoptosis and inhibit cell proliferation in various tumor types.

Adding to its pluripotent anti-cancer effects, resveratrol has a good pharmacokinetic profile in animals leading to high absorption in the gut $(88,89)$. Furthermore, its solubility makes it a suitable candidate for testing in clinical trials (89). The metabolites of resveratrol also retain the original chemopreventive activity, a key factor one should consider when using this agent in chemoprevention trials (90). A Phase-1 interventional, open label prevention trial has studied the side effects of oral resveratrol administration over 4 weeks to establish 
the mechanism through which it prevents cancer http://clinicaltrials.gov/ct2/show/ NCT00098969. This study measured the drug and carcinogen metabolizing enzymes, primarily cytrochrome $\mathrm{P} 450$, in blood and urine collected from study participants who have taken resveratrol.

Although in vitro studies using resveratrol show potent anti-melanoma activity, an in vivo study found that resveratrol is rapidly metabolized in athymic nude mice and does not inhibit human melanoma xenograft growth (91). Administration of 110 or $263 \mu \mathrm{M}$ resveratrol in diet prior to subcutaneous injection of tumor cells had no tumor inhibitory effect, instead mice treated with the highest resveratrol concentration had bigger tumors compared to control diet fed animals (91). Authors of this study hypothesized that rapid clearance as well as transformation of resveratrol when given in diet might be responsible for this tumor promoting effect (91). Further experiments designed to circumvent the rapid clearance of resveratrol when administered through oral gavage or in diet have also failed to inhibit tumor growth indicating that resveratrol on its own is not an effective chemopreventive agent for inhibiting melanoma development (91).

Derivatives of resveratrol with greater stability and efficacy have been created by chemical modifications and tested in vitro as well as in mouse models. Results of these studies identified that hydroxylated analogs of resveratrol might be more potent than resveratrol ( 92 , 93). For example, hexahydroxystilbene (M8) effectively inhibited COX-2 activity to inhibit the growth of various tumor cell lines at very low concentrations $(93,94)$. In vivo, intraperitoneal administration of M8 at $2.5 \mathrm{mg} / \mathrm{kg}$ or $5 \mathrm{mg} / \mathrm{kg} / \mathrm{day}$ for 4 weeks alone as well as in combination with $80 \mathrm{mg} / \mathrm{kg}$ DTIC (on days 4 and 6) inhibited the growth of palpable melanoma tumors in xenografted mice models $(92,94)$. In addition, M8 could also inhibit melanoma tumor metastasis as evidenced by decreased tumor development in the lymph nodes $(92,94)$. Although these preliminary findings are encouraging, further studies evaluating M8 in Phase-I and Phase-II trials in humans are needed. It is also unknown whether M8 could be combined with FDA approved ${ }^{\mathrm{V} 600 \mathrm{E}} \mathrm{B}$-Raf inhibitor Vemurafenib, and Akt inhibitor MK-2206 to cooperatively or synergistically inhibit melanoma development. Therefore future studies should try these combinations for preventing melanomas.

Silymarin-Silymarin, a polyphenolic flavonoid isolated from Silybum marianum (milk thistle), is a potent antioxidant and anti-inflammatory agent $(95,96)$ (Figure 3). Silymarin is a mixture of 4 isomeric compounds namely silybinin, silychristin, silydianin, isosilybinin $(95,96)$ (Figure 3). Studies using cultured cells and animal models demonstrated its chemopreventive ability against non-melanoma skin cancers induced by chemical carcinogens and UV-radiation (97). Mechanistically, silymarin inhibits NF-kB, c-Jun Nterminal kinase, and COX-2 activities (98). In addition, it also suppresses the production of reactive oxygen species thereby preventing DNA damage. Silymarin also inhibits cell proliferation by inducing a G0/G1 block, and suppresses invasion by inactivating PI3K-Akt as well as MAPK pathways $(98,99)$. Recent studies have demonstrated that silymarin inhibits melanoma cell migration by reducing MMP-2 as well as MMP-9 protein levels (100). Further studies identifying the mechanistic basis of UV-induced melanoma chemoprevention showed that silymarin inhibits immunosuppressive IL-10 production in the skin as well as in draining lymph nodes (101). In addition, silymarin also acts on immune system stimulating IL-12 to increase its levels thereby protecting cells from UV-induced damage (102). For example, topical application of silymarin prevented UV-induced immune suppression only in wild-type mice but not in IL-12 knockout mice (102).

Epigallocatechin-3-gallate (EGCG)_EGCG, a major constituent of green tea, has been shown to protect from UV-induced skin cancers by inhibiting DNA damage and oxidative stress (103-105) (Figure 3). Experimentally, topical application of EGCG inhibited the 
reduction of antioxidants such as glutathione peroxidase and catalase in the epidermis, thereby protecting cells from oxidative stress $(103,105,106)$. Studies have demonstrated that topical application or oral administration of EGCG reduced cutaneous edema and erythema, and decreased the incidence of tumor incidence, multiplicity and size $(105,107)$. In cultured cells, treatment of metastatic A375M and Hs-294T melanoma cells with EGCG inhibited oncogenic BCL2, and upregulated Bax as well as caspase-3, 7, \& 9 expression in a dose-dependent manner (106). In addition, EGCG also reduced the expression of the proliferation regulator cyclin-D1 and induced cell cycle inhibitors p16, p21 and p27 (106). Furthermore, in murine models of melanoma, EGCG reduced cell migration, induced apoptosis and triggered cell cycle arrest thereby inhibiting melanoma tumor growth and the metastatic potential of the cells (108). Additional studies showed effective anti-angiogenic properties of EGCG, as this compound reduced the production of VEGF $(109,110)$. Since EGCG is less expensive and has negligible toxicity, it is an attractive candidate chemopreventive agent, however, no clinical trials data using EGCG has been reported, warranting further study.

Selenium-containing agents for preventing melanoma-Anti-cancer activity of selenium has been suggested for preventing cancers of the prostate, breast and lung (111). Many in vitro and in vivo studies also tested various selenium containing compounds for inhibiting proliferation and inducing apoptosis as well as triggering cell cycle arrest (40, 112). However, a multicenter, double-blinded, randomized, placebo-controlled trial of 1,312 patients (mean age 63 years) with a history of BCC or SCC and a mean follow-up of 6.4 years showed that $200 \mu \mathrm{g}$ of selenium in the form of brewer's yeast tablets did not have a statistically significant effect on BCC or SCC development (113). But, results from secondary end-point analyses showed that supplemental selenium might reduce the incidence (77 cancers in the selenium group and 119 in controls) and mortality rates from carcinomas (29 deaths in the selenium treatment group and 57 deaths in controls) (113). However, authors of this study stated that these results need further evaluation before considering for testing in clinical trials.

Recently, selenomethionine was tested for its efficacy in a large multi-center chemoprevention trial, known as SELECT (selenium and vitamin E cancer prevention trial) trial, for preventing prostate cancer (114-116) (Figure 3). Results of the SELECT trial have raised further concerns regarding the clinical utility of selenium for chemoprevention (114116). SELECT is the largest clinical trial ever-conducted for prostate cancer prevention (114-116). The trial, sponsored by NCI ( $\$ 114$ million) and NCCAM ( $\$ 4.5$ million) from 1999-2008, was initiated based on results of the NPC trial showing 52-60\% fewer new cases of prostate cancer following selenized yeast treatment compared to placebo $(113,117)$. SELECT was a double-blinded placebo controlled study examining the role of nutritional supplementation of selenomethionine and/or vitamin $\mathrm{E}$ for preventing prostate cancer (114). Based on the experts' opinion and available compelling evidences showing the efficacy of selenium containing yeast in preclinical data, SELECT study group decided to use $200 \mu \mathrm{g}$ selenomethionine for the trial. Participant men between 50-55 years old with no history of prostate cancer and in good health, took pills constituting one of four possible combinations: two placeboes; $200 \mu \mathrm{g}$ selenomethionine and a placebo; vitamin E and a placebo or selenomethionine and vitamin $\mathrm{E}$ daily for 7-12 years with follow-up visits every 6-months for $7-12$ years. It was predicted to decrease prostate cancer at $225 \%$ (114). Whereas selenized yeast reduced the incidence of prostate cancer in the NPC trial, the same trend was not observed in SELECT using selenomethionine. On September $15^{\text {th }} 2008$, the data and safety monitoring committee announced that all SELECT participants must discontinue supplements because, although statistically insignificant, more prostate cancer cases occurred in men taking only vitamin $\mathrm{E}$ and an increase in diabetes was noticed in the selenium groups. 
Despite these negative results for inhibiting basal cell carcinoma (BCC) and squamous cell carcinoma (SCC) with selenized yeast, use of selenium for preventing human skin cancers continues to be investigated. Possible reasons for considering selenium for melanoma prevention include: (a) very low selenium levels observed in the serum of melanoma patient's; (b) an inverse correlation between the selenium concentration and melanoma incidence rates in population based studies; (c) encouraging in vitro as well as in vivo studies demonstrating the efficacy of selenium for preventing melanomas; (d) feasibility of substituting selenium for sulfur for improving the efficacy of various chemopreventive agents; and (e) availability of a wide variety of selenium containing compounds for better agent selection $(118,119)$. In fact, several selenium-containing agents have been prepared and tested in vitro as well as in vivo for safety and efficacy $(120,121)$.

Isolated soy proteins generated from high-Se as well as low-Se soybeans have been tested for efficacy to inhibit pulmonary metastasis of mouse melanoma cells (122). Analysis of experimental data revealed an inverse correlation between selenium content of the mice and metastasis development (122). Experimentally, ISP differing in selenium content has been given to mice two weeks before and after administration of B16BL6 mouse melanoma cells and metastasis development in lungs quantified (122). The results showed a significant decrease in tumor number and tumor size in the 10\% high-Se ISP diet that contained $3.6 \mu \mathrm{g} /$ $\mathrm{g}$ Se compared to $10 \%$ low-Se ISP diet having $0.13 \mu \mathrm{g} / \mathrm{g}$ Se (122). Furthermore, addition of selenomethionine to the $10 \%$ low-Se ISP diet to levels equivalent to $10 \%$ high-Se ISP diet inhibited metastasis development similar to $10 \%$ high-Se ISP diet indicating that the active ingredient responsible for metastasis development inhibition in the high-Se ISP could be selenomethionine (122).

Several other studies also have shown the ability of selenomethionine to inhibit metastasis development in animal models (123) (Figure 3). For example, diet containing selenomethionine, one of the major constituents of selenized yeast, has been shown to inhibit pulmonary metastasis in a mouse model (123). Experimentally, mice were given a diet containing $2.5 \mathrm{ppm}$ or $5 \mathrm{ppm}$ selenium as selenomethionine (experimental group) or as selenite (control group) two weeks before and after the intravenous injection of B16BL-6 murine melanoma cells and the effect on number as well as size of the tumors developing in lungs measured (123). Authors of this study found that selenium in the form of selenomethionine or selenite could reduce lung metastasis, hence, selenomethionine is an active form of selenium (123).

In addition to selenomethionine, the effect of p-XSC on lung metastasis development also found decreased metastatic tumor nodules when the mice were fed with this agent (124) (Figure 3). Mice were fed with experimental diets containing 4, 8, $15 \mathrm{mg} / \mathrm{kg} \mathrm{p}-\mathrm{XSC}$ (corresponds to 2, 4, $7.5 \mathrm{mg} / \mathrm{kg}$ selenium) before and after inoculation B16BL-6 cell intravenously (124). Compared to controls, p-XSC fed mice were found to contain low melanoma lungs metastasis (124). Mechanistic studies found that p-XSC could induce apoptosis in melanoma cells without affecting neighboring epithelial cells thereby reducing tumor development in the lungs (124). Further studies have demonstrated that p-XSC can also inhibit tumor angiogenesis as well as proliferation of melanoma cells (124). Hence, pXSC could be a potential candidate for testing in phase clinical trials. However, to date, no such trials have been conducted in melanomas warranting further evaluation of this agent.

Whereas selenomethionine, high-Se ISP, and p-XSC treatments reduced the metastasis development, efficacy against melanoma tumor development and progression were not studied. Therefore, it is unknown whether selenium could inhibit very early events in melanoma development, and if so, could selenium be used to prevent melanoma tumor growth in its very earliest stages. Recent studies have synthesized selenium containing 
isoselenocyanates as well as isoselenoureas by substituting sulfur of parent isothiocyanates and PBIT with selenium $(112,120,121,125,126)$ (Figure 3). Results of in vitro and in vivo studies using laboratory generated skin-reconstructs and xenografted melanoma tumor models found greater tumor inhibition with selenium containing derivatives $(40,112)$. Topical application of ISC-4 and PBISe significantly delayed xenografted melanoma tumors growth $(40,112)$. Two weeks after topical treatment, a 50 to $70 \%$ decrease in tumor volume was observed $(40,112)$. Furthermore, topical administration of these compounds was safe with no major differences in vital organ function or in blood parameters indicative of major organ functions $(40,112)$. Therefore, selenium might be useful for prevention of melanomas if provided in the correct form and dosage. Although both ISC-4 and PBISe inhibited growth of melanocytic nevi in laboratory-generated skin reconstructs as well as in subcutaneous xenografted melanoma tumors, efficacy and safety of these agents in humans remains to be established.

The mechanism through which selenium containing compounds function seems to vary and can affect efficacy. Recent studies have shown that ISC-4 could inhibit carcinogen induced DNA adducts formation as well as modulate both phase-I and phase-II enzymes to prevent lung cancer development (127) (Figure 3). In melanomas, ISC-4 reduced the Akt3 signaling activity thereby inhibiting melanoma cell proliferation and inducing apoptosis (121). In a separate study, ISC-4 has been shown to activate prostate apoptosis response protein-4 (Par-4) expression thereby inhibiting tumor development in mice (128).

PBISe is another selenium containing compound found effective at inhibiting melanomas $(40,120,126)$ (Figure 3). Compared to its sulfur-containing analog PBIT, this compound effectively inhibited cell proliferation as well as survival of melanoma cells growing in culture $(40,120,126)$. PBISe also retarded the growth of melanocytic nevi developing in skin reconstructs (40). Mice receiving PBISe intraperitoneally or through topical application exhibited slow tumor growth compared to PBIT or vehicle controls $(40,120,126)$.

Mechanistically, PBISe inhibited iNOS and Akt3 pathways, while inducing pErk1/2 expression (40). Elevated expression and activity of iNOS as well as Akt3 have been reported in melanoma $(129,130)$. Targeted inhibition of iNOS and Akt3 have been shown to reduce cell proliferation and induce apoptosis $(129,131)$. In addition, PBISe induced the phosphorylation of endogenous Erk1/2 to levels that triggers senescence by upregulating proliferation inhibitor p27 in melanoma cells (132). Therefore, PBISe could be a potent antimelanoma agent.

Non-steroidal anti-inflammatory drugs (NSAIDs)—Use of NSAIDs for preventing cancers has been reported by several investigators with good safety and health beneficial effects compared other chemopreventive agents (133). In addition, many in vitro studies using cultured cells as well as mouse models showed efficacy of NSAIDs for preventing melanomas (134). Interestingly the primary target of NSAIDs, COX2 is expressed at a very high level in $>93 \%$ patient tumors as well as in the majority of melanoma cell lines (135). Many studies have shown the protective effects of NSAIDs for inhibiting colorectal cancers when used for extended periods of time ( $>5$ years) with frequent administration. Similarly several in vitro and observational studies testing the long-term use of NSAIDs and statins found reduced cutaneous melanoma development (136). However, some conflicting reports have hampered further development of NSAIDs for cutaneous melanoma prevention (134, 137, 138). For example, a large cohort study measuring the association between NSAIDs use and melanoma risk found no association indicating that the NSAIDs may not be good for melanoma chemoprevention (138). In this study 63809 men and women from VITAL (vitamins and lifestyle) cohort study were linked to NCI Surveillance, Epidemiology and End Results (SEER) cancer registry to determine whether NSAIDs use in the past 10 years had any association with melanoma risk (138). Furthermore, this study also pointed that use 
of NSAIDs has no impact on tumor invasion, thickness and metastasis (138). However, a recent case-control study measuring the prevalence of cutaneous melanoma among populations using lipid lowering agents and NSAIDs reported that long-term use of at least one NSAID for $>5$ years decreased the likelihood of developing cutaneous melanoma by half compared with those who taken NSAID for $<2$ years or who had not taken these antiinflammatory agents (47).

Acetyl salicylic acid (ASA) has been reported to half the risk of developing cutaneous melanoma compared to non-users or those who used ASA for < 2 years (47) (Figure 3). Protective effects of ASA are primarily attributed to its influence on various signaling cascades regulating cell proliferation and survival (47). For example ASA, has been reported to inhibit oncogenic NF-kB as well as BCL2, while upregulating the levels of tumor suppressor TP53, CDKN1A and BAX $(139,140)$. While some studies have shown an inverse association between NSAIDs use and risk of developing cutaneous melanomas, other reported none $(47,138)$. These conflicting results necessitate the need for further studies to confirm the clinical utility of NSAIDs for preventing melanomas. For example, in a prospective cohort study investigating the association between over-the-counter selfreported NSAIDs use and melanoma risk, no association was found (138).

Beta carotene-Beta carotene is a potent antioxidant known to exhibit photoprotective effects and anticancer activity (141) (Figure 3). For example, an in vitro study using mouse melanoma models showed inhibition of angiogenesis as well as nuclear localization of transcription factors and induction of BAX mediated apoptosis by beta-carotene $(142,143)$. A physicians' health study consisting of 21,884 male physicians showed that administration of $50 \mathrm{mg} / \mathrm{kg}$ daily oral beta carotene for $\sim 12$ years had no effect on the incidence of BCC and SCC (144). Similarly, a separate community based randomized trial with betacarotene in 1621 study participants from Nambour district, Southeast Queensland, Australia found that beta carotene alone and in combination with a sunscreen having a SPF-15 also had no beneficial effects for preventing the incidence of basal cell carcinoma (145). Therefore, use of beta-carotene for preventing progression and metastasis of melanoma is questionable. However, combination trials using beta-carotene needs to be conducted before excluding this potent antioxidant from chemoprevention use.

Celecoxib-Celecoxib is a selective inhibitor of cyclooxygenases (146). Cyclooxygenase (COX, EC1.14.99.1) is an oxygenase responsible for the production of biological mediators prostaglandins, prostacyclin and thromboxanes from arachidonic acid (AA) (147, 148)

(Figure 3). COX is also called prostaglandin synthase (PHS) and prostaglandin endoperoxide synthase (EPS) (149). Three COX isoforms COX-1, COX-2 and COX-3 (a splice variant of COX-1) have been identified in human tissues (149). Although all COX isoforms are structurally similar (sharing $>65 \%$ amino acid homology and having nearidentical catalytic sites) and perform similar catalytic reactions, the tissue distribution and expression levels in response to various stimuli differs (149). For example, COX-1 is a constitutive enzyme, whereas COX-2 is inducible in most instances (149). In addition, COX-2 expression is elevated in the majority of tumors and is selectively inhibited by various pharmacological agents (150). Studies measuring the expression levels of COX-2 in melanomas found very high protein levels in early and late-phase melanoma patients compared to normal human melanocytes (147). Furthermore, levels of COX-2 were also upregulated when mice were exposed to UV light indicating a potentially important role of COX-2 expression in melanoma tumorigenesis (151). Similarly, COX-2 expression was elevated when human skins were exposed to UV radiation (152). Additional studies also showed that targeted inhibition of COX-2 using siRNA or pharmacological agents could inhibit melanoma tumor growth and sensitizes cells to radiation (153). 
A separate study evaluated the efficacy of celecoxib for preventing actinic keratosis in a double-blind, randomized, placebo-controlled trial (154). Administration of $200 \mathrm{mg}$ celecoxib twice daily to 240 high-risk men and women having 10 to 40 actinic keratoses and a history of previous skin cancer resulted in no response in terms of the incidence of actinic keratosis (154). Therefore, the utility of celecoxib for treating non-melanoma skin cancers was unclear. Further studies are therefore warranted to determine whether COX-2 is a potential chemopreventive target, and, if so, what level of COX-2 inhibition is required for cancer prevention.

In vitro studies using other COX-2 inhibitors showed that COX-2 is an effective chemopreventive target for reducing the metastatic potential of melanoma cells (155). Naturally occurring inhibitors such as berberine inhibited melanoma cell proliferation and metastasis by targeting COX-2 and ERK pathways (156). Another study tested the ability of celecoxib for preventing melanoma in 27 patients with surgically incurable recurrent melanoma (146). Data showed tumor regression in 7 patients, among whom 2 patients had complete regressions, 2 experienced partial regressions, and 3 showed a mixed response (146). The median overall survival time from first incurable metastasis was 31.9 months (146). Analysis of median times to progressive disease and death from start of celecoxib was 4.3 months and 10.4 months, respectively (146). Although results of this study are encouraging, celecoxib failed to show similar efficacies in all patients despite the presence of high COX-2 expression, indicating the level of inhibition might not be sufficient to prevent melanoma development in certain cases, warranting the development of more potent COX-2 inhibitors.

Since targeting COX-2 alone failed to lead to complete tumor inhibition in vitro as well as in vivo, further studies considered testing COX-2 inhibitors in combination trials (157). For example, a combination of COX-2 inhibitor celecoxib and 5-fluorouracil (5-FU) reduced the number of UV-B induced skin tumors $70 \%$ more effectively in mice compared to either single agent (157). Mechanistically, in addition to the inhibition of cell cycle, celecoxib also facilitated the diffusion of 5-FU in to tumor cells thereby increasing its efficacy to inhibit cell proliferation (157).

Alpha-difluoromethylornithine-Alpha-difluoromethylornithine (DFMO), also known as eflornithine, is an irreversible inhibitor of ornithine decarboxylase and is involved in inhibiting polyamine production (158) (Figure 3). Several in vitro and mice studies have shown the efficacy of DFMO for inhibiting pulmonary melanoma metastases $(158,159)$. For example a preclinical study evaluating the efficacy of DFMO in malignant mouse B16 amelanotic melanoma (B16a) showed a dose-dependent decrease in the tumor growth and pulmonary metastasis development. Administration of $0.5,1$ and $2 \%$ DFMO in water, inhibited tumor growth by $0,24.5$ and $60 \%$, while the same doses reduced metastasis by 55 , 83 and 96\% (158). Since administration of DFMO did not inhibit the experimental metastasis, authors of this study concluded that DFMO might be affecting invasion of melanoma cells (158). A separate study tested the efficiency of DFMO in combination with Type I interferon in melanoma mouse models $(160,161)$. The data showed the antiproliferative potential of DFMO, both alone and in combination in several tumor cell lines. For example, treatment of B16 melanoma cells with DFMO inhibited the growth with an $\mathrm{IC}_{50}$ of $31.1 \mu \mathrm{M}$. However, when used in combination, DFMO exhibited a marked synergism with Type I interferon. Mechanistically, DFMO enhanced the therapeutic efficacy of interferon treatment by controlling interferon receptor down-regulation.

A previous Phase-II study using DFMO ( $2 \mathrm{~g} / \mathrm{m} 2 \mathrm{po}, \mathrm{q} 8 \mathrm{~h}$ ) in 21 evaluable patients showed a complete response in 1 patient for 11 months (162). Seven other patients presented with stable disease for 8 weeks (162). However, due to toxicity and hearing loss observed in 5 
patients, further use of DFMO was discouraged (162). Further studies are warranted to determine whether using a different DMFO schedule would prevent hearing loss (162). Future trials should also consider using DMFO in combination with other agents. A separate investigation has examined the antitumor and antimetastatic activities of DFMO by inducers of interferon, namely, tilorone and polyriboinosinic:polyribocytidilic acid complex [poly(l) $\mathrm{X}$ poly $(\mathrm{C})]$ (161). Results of these combination trials indicated that interferon inducers enhanced the antitumor activity of DFMO against B16 melanoma in mice (161). DFMO, tilorone, or poly(l) X poly(C), when administered alone, showed 85,39 , and $39 \%$ of inhibition of tumor growth, respectively (161). However, a combination of DFMO and tilorone or poly(l) X poly (C) resulted in 98 and 95\% growth inhibition (161). Efficacy was linked to induction of interferon (161). Other studies with Lewis lung carcinoma cells also showed similar DFMO potentiating effects of interferons $(161,163)$. A combination of DFMO and tilorone led to $78 \%$ inhibition of tumor growth and $99.5 \%$ inhibition of metastases, but the mechanisms remain to be fully elucidated $(161,163)$. Enhancement of host immune response or interferon-mediated cytotoxicity would likely be the mechanism of action $(161,163)$.

Sunscreens-Sunscreens are topically applied creams or gels protect underlying skin cells from UV-induced damage (164). Use of sunscreens is widely advocated as a preventive measure against sun-induced skin cancers (165). However, to date, no epidemiologic study has reported decreased melanoma risk associated with sunscreen use (166). Furthermore, results from a collaborative European case-control study and animal studies have raised concerns about the protection sunscreens provide against UV radiation-associated cutaneous melanomas $(21,167,168)$. Moreover, meta-analysis of 18 studies investigating the association between melanoma risk and previous sunscreen use, suggested little or no beneficial correlation $(169,170)$. Therefore, although sunscreens are known to act as physical barriers protect skin from UV induced damage, the role of these agents for preventing skin-cancers requires further investigation. This is especially important since some studies suggest that increased skin cancer risk when sunscreens were used $(18,19$, 171, 172). Therefore, it is currently unknown whether sunscreens that have been designed to reduce exposure to UV radiation will reduce skin cancer incidence in humans. In addition, since host factors such as propensity to burn, variable numbers of benign melanocytic nevi, and atypical nevi may also increase the risk of developing cutaneous melanoma, clinical trials should consider these influencing factors while evaluating and testing the efficacy of sunscreens for preventing melanoma (173-176).

A very small randomized placebo-controlled study with 53 volunteers who had either clinical evidence of solar keratoses or non-melanoma skin cancer was conducted using a sunscreen with a SPF of 29 (177). The study showed, among 37 participants, a decrease rate of new solar keratoses after 2 years using sunscreen compared to the placebo group (177). Another randomized controlled study evaluating the effect of regular sunscreen with SPF of 17 on solar keratoses in 431 patients demonstrated that individuals in the sunscreen group developed fewer new lesions and more remission of existing lesions than those in the basecream placebo group http://www.cancer.gov/cancertopics/pdq/prevention/skin/

HealthProfessional/page4. Furthermore, the development of new lesions and the remission of existing lesions had been reported to correlate with the amount of sunscreen used. In contrast, a separate randomized study (the Nambour Skin Cancer Prevention Trial from Australia) showed no statistically significant difference in incidence of BCCs or SCCs with regular SPF-16 sunscreen use (145).

According to the Nambour Skin Cancer Prevention Trial, which compared incidence of melanoma between randomly assigned daily or discretionary sunscreen use, an increase in the number of melanomas in the discretionary-use group was found (145). Whereas eleven 
melanomas ( 3 of them invasive) were diagnosed in the daily sunscreen group, about 22 melanomas have been identified with half of them being invasive in the discretionary-use group (145). Furthermore, no difference was noticed in rates of melanoma on prescribed sunscreen application sites between the two groups (145). Although, results of this study indicate no protective effect of sunscreen on melanoma incidence, this study has several important limitations (145). For example, (a) melanoma was not the primary planned endpoint of the original trial, hence the selection of study subjects and end-points might not be as effective when melanoma is considered as the primary outcome; (b) the confidence intervals (CIs) of the outcome estimates are very wide, demonstrating substantial uncertainty regarding the magnitude of the effect; and (c) widespread use of the passive participant option during the follow-up phase of the study (145). In contradiction with the Nambour Skin Cancer Prevention Trial, a recent separate study using sunscreens of SPF-15 demonstrated that the incidence of squamous-cell carcinoma was significantly lower in the sunscreen group compared to the groups not using it (178).

A separate case-control study with 418 melanoma cases and 438 healthy individuals also recently evaluated the influence of sunscreen use on the occurrence of cutaneous malignant melanoma (179). This study found increased melanoma risk among psoralen sunscreen users compared to regular sunscreen users (179). The melanoma risk was 1.5 for regular sunscreen users whereas for psoralen sunscreen users it was 2.28 suggesting a negative influence of the psoralen sunscreen (179). This study supports the hypothesis that sunscreens do not protect against melanoma. This negative correlation with sunscreens use could be due to the prolonged exposure to unfiltered UV radiation, which induces melanoma formation. In support of this hypothesis, a separate study in mice testing the effect of sunscreens on UV radiation induced melanoma found increased melanoma cell growth in sunscreen utilization group compared to controls (168). $\mathrm{C} 3 \mathrm{H}$ mice were exposed to UVB radiation twice a week for 3 weeks (168). The sunscreens contain ED 7.5\% 2-ethylhexyl-p-methoxycinnamate, $8 \%$ octyl-N-dimethyl-p-aminobenzoate, $6 \%$ benzophenone-3, or the oil-in-water vehicle alone applied to the ears and tails of mice 20 minutes before irradiation and the UV induced inflammation as well as histological alterations were measured (168). Injection of melanoma cells in to the external ears created melanomas in both control and experimental animals (168). Although sunscreens protected from UV radiation-induced ear damage, they failed to protect from melanoma indicating that the protection against sunburn does not necessarily imply protection against melanoma growth (168). A comprehensive MEDLINE search analysis of reports published between 1966 and 2003 about the use of sunscreens and melanoma protection also showed no association (170). Furthermore, this meta-analysis study suggests that the positive association reported in some prior studies could be due to failure to control for confounding factors such as the sensitivity to sun, age of the patient, frequency and type of sunscreen use.

Betulinic acid-Betulinic acid is a triterpene isolated from the bark of Betula pubescens (180) (Figure 3). Betulinic acid has been found to kill several cancer types including melanoma $(180,181)$. Betulinic acid inhibited melanoma tumor development in mice without causing systemic toxicity (180). Mechanistically, betulinic acid induced apoptosis in a p53- and CD95-independent manner in cancer cells to inhibit tumor development (182). Other studies have suggested involvement of reactive oxygen species, inhibition of topoisomerase I, activation of Erk1/2 phosphorylation, suppression of tumor angiogenesis, and modulation of pro-growth transcriptional activators as well as aminopeptidase $\mathrm{N}$ activity for betulinic acid chemopreventive activity (183). Due to encouraging in vitro and in vivo studies, safety and cost effectiveness, betulinic acid is currently being evaluated for the prevention of malignant melanomas $(184,185) \mathrm{http}: / / \mathrm{clinicaltrials.gov/ct2/show/}$ NCT00346502. Recently, betulinic acid was also found to be effective at preventing smalland non-small-cell lung, ovarian, cervical, and head \& neck carcinomas (183). 
While betulinic acid inhibits the growth of many cancer cells in vitro, a separate study comparing the efficacy of betulinic acid for inhibiting the MeWo melanoma cells (both drug sensitive and drug resistant) compared to normal melanocytes demonstrated greater cytotoxicity to normal melanocytes, which could be a concern (184). Another study showed increased sensitivity of keratinocytes to betulinic acid treatment compared to melanoma cells (186). Therefore, additional experimentation is required to dissect the mechanistic basis for this effect on normal cells. Molecular mechanisms inducing resistance to betulinic acid have been investigated and found the involvement of the PI3K-Akt pathway (187). Since betulinic acid induces apoptosis by activating the Erk pathway and decreasing CDK4 expression, inhibitors reducing MEK1/2 activity such as U0126 have been reported to induce resistance to betulinic acid (188). Furthermore, resistance to betulinic acid could be due to induction of Akt activity and survivin expression (187). Betulinic acid first upregulates EGFR phosphorylation to promote Akt as well as survivin expression (187). Targeted inhibition of EGFR using PD153035 decreased betulinic acid induced EGFR phosphorylation and inhibited Akt activation to promote cancer cell destruction (187). Compound combination studies have observed synergistic inhibition of cancer cell growth when betulinic acid is combined with PD153035, suggesting the new direction for future clinical trials (187). Betulinic acid has also been reported to inhibit the migration of melanoma cells (188). For example, human metastatic C8161 melanoma cells but not their non-metastatic variant $\mathrm{C} 8161 /$ neo6.3 were found to be more susceptible to betulinic acid treatment (188). In these cells, betulinic acid induced p53 expression thereby inducing apoptosis $(189,190)$. A phase I/II, study (NCT00346502) is currently evaluating the efficacy of $20 \%$ betulinic acid ointment for determining the safety and efficacy for decreasing dysplastic nevi from transforming into melanomas http://clinicaltrials.gov/ct2/show/ NCT00346502.

Vitamin-D-In vitro and in vivo studies using vitamin-D as a chemopreventive agent for melanoma demonstrated reduced tumor growth $(191,192)$ (Figure 3). Furthermore, a large case-control study using dietary vitamin-D found it reduced melanoma risk (193). However, recent studies showed lack of melanoma inhibitory activity for vitamin-D, which raised concerns regarding use of this natural product for preventing melanoma (194). A pilot study is underway to evaluate the effect of vitamin-D on melanocyte biomarkers (NCT01477463). The purpose of this study is to identify the signaling pathways and changes in gene expression in melanocytes of patients with a history of non-melanoma skin cancer who are exposed to oral vitamin D http://clinicaltrials.gov/ct2/show/NCT01477463. If vitamin D inhibits a signaling pathway involved in the development of melanoma, such as ${ }^{\mathrm{V} 600 \mathrm{E}} \mathrm{BRAF}$ protein involved in cell proliferation, then oral vitamin $\mathrm{D}$ could be explored further as a chemoprevention. The results of this trial are pending.

\section{CONCLUSIONS}

Chemoprevention of melanoma if successful could be used to prevent the transformation of nevi into invasive melanomas, which could reduce the incidence of this deadly disease. Even though several chemopreventive agents have been developed, currently, no single agent is effective for preventing melanomas, which is driving the search for more potent compounds or compound combinations having greater chemopreventive efficacy. Although encouraging data has been reported with selenium containing isoselenocyanates as well as isoselenoureas in laboratory generated skin reconstructs as well as xenografted animal models, further studies are required to determine the safety and efficacy of these agents for human use. Similarly, studies are also warranted to determine the efficacy of naturally occurring, cost effective compounds such as curcumins and EGCGs for melanoma prevention. 


\section{FUTURE DIRECTIONS}

Future studies aiming at effective melanoma chemoprevention should consider (a) using targeted nano-technologies for effective delivery of chemopreventive agents; (b) determining the efficacy of compound derivatives such, as those for curcumin, for safety and efficacy; (c) developing better preclinical models for evaluating the chemopreventive efficacy of various agents; and, (d) evaluating various compound combinations primarily focusing on target based preventive strategies.

\section{Acknowledgments}

Grant support: NIH CA-127892-01A and The Foreman Foundation for Melanoma Research (GPR).

\section{References}

1. Sporn MB, Dunlop NM, Newton DL, Smith JM. Prevention of chemical carcinogenesis by vitamin A and its synthetic analogs (retinoids). Fed Proc. 1976; 35:1332-8. [PubMed: 770206]

2. Sporn MB, Dunlop NM, Newton DL, Henderson WR. Relationships between structure and activity of retinoids. Nature. 1976; 263:110-3. [PubMed: 987541]

3. Lippman SM, Hong WK. Cancer prevention science and practice. Cancer Res. 2002; 62:5119-25. [PubMed: 12234971]

4. Lippman SM, Hong WK. Cancer prevention by delay. Commentary re: J. A. O’Shaughnessy et al., Treatment and Prevention of Intraepithelial Neoplasia: An Important Target for Accelerated New Agent Development. Clin. Cancer Res 8: 314-346, 2002. Clin Cancer Res. 2002; 8:305-13. [PubMed: 11839646]

5. Balch CM, Buzaid AC, Soong SJ, et al. Final version of the American Joint Committee on Cancer staging system for cutaneous melanoma. J Clin Oncol. 2001; 19:3635-48. [PubMed: 11504745]

6. Lao CD, Demierre MF, Sondak VK. Targeting events in melanoma carcinogenesis for the prevention of melanoma. Expert Rev Anticancer Ther. 2006; 6:1559-68. [PubMed: 17134361]

7. Jordan VC. Chemoprevention of breast cancer with selective oestrogen-receptor modulators. Nat Rev Cancer. 2007; 7:46-53. [PubMed: 17186017]

8. Freedman AN, Graubard BI, Rao SR, McCaskill-Stevens W, Ballard-Barbash R, Gail MH. Estimates of the number of US women who could benefit from tamoxifen for breast cancer chemoprevention. J Natl Cancer Inst. 2003; 95:526-32. [PubMed: 12671020]

9. Weinberg JM. Topical therapy for actinic keratoses: current and evolving therapies. Rev Recent Clin Trials. 2006; 1:53-60. [PubMed: 18393780]

10. Demierre MF, Nathanson L. Chemoprevention of melanoma: an unexplored strategy. J Clin Oncol. 2003; 21:158-65. [PubMed: 12506185]

11. Pathak MA. Ultraviolet radiation and the development of non-melanoma and melanoma skin cancer: clinical and experimental evidence. Skin Pharmacol. 1991; 4 (Suppl 1):85-94. [PubMed: 1764252]

12. Husain Z, Pathak MA, Flotte T, Wick MM. Role of ultraviolet radiation in the induction of melanocytic tumors in hairless mice following 7,12-dimethylbenz(a)anthracene application and ultraviolet irradiation. Cancer Res. 1991; 51:4964-70. [PubMed: 1909931]

13. Robertson GP. Functional and therapeutic significance of Akt deregulation in malignant melanoma. Cancer Metastasis Rev. 2005; 24:273-85. [PubMed: 15986137]

14. Madhunapantula SV, Robertson GP. Therapeutic Implications of Targeting AKT Signaling in Melanoma. Enzyme Res. 2011; 2011:327923. [PubMed: 21461351]

15. Abdel-Malek ZA, Kadekaro AL, Swope VB. Stepping up melanocytes to the challenge of UV exposure. Pigment Cell Melanoma Res. 2010; 23:171-86. [PubMed: 20128873]

16. Lund LP, Timmins GS. Melanoma, long wavelength ultraviolet and sunscreens: controversies and potential resolutions. Pharmacol Ther. 2007; 114:198-207. [PubMed: 17376535]

17. Quinn AG. Ultraviolet radiation and skin carcinogenesis. Br J Hosp Med. 1997; 58:261-4. [PubMed: 9488800] 
18. Planta MB. Sunscreen and melanoma: is our prevention message correct? J Am Board Fam Med. 2011; 24:735-9. [PubMed: 22086817]

19. Goldenhersh MA, Koslowsky M. Increased melanoma after regular sunscreen use? J Clin Oncol. 2011; 29:e557-8. author reply e859. [PubMed: 21537031]

20. Barton MK. Sunscreen use in adults is beneficial in preventing melanoma. CA Cancer J Clin. 2011; 61:137-8. [PubMed: 21532097]

21. Loden M, Beitner H, Gonzalez H, et al. Sunscreen use: controversies, challenges and regulatory aspects. Br J Dermatol. 2011; 165:255-62. [PubMed: 21410663]

22. Walker G. Cutaneous melanoma: how does ultraviolet light contribute to melanocyte transformation? Future Oncol. 2008; 4:841-56. [PubMed: 19086850]

23. Wang HT, Choi B, Tang MS. Melanocytes are deficient in repair of oxidative DNA damage and UV-induced photoproducts. Proc Natl Acad Sci U S A. 2010; 107:12180-5. [PubMed: 20566850]

24. Bennett DC. Ultraviolet wavebands and melanoma initiation. Pigment Cell Melanoma Res. 2008; 21:520-4. [PubMed: 18821857]

25. Bennett DC. How to make a melanoma: what do we know of the primary clonal events? Pigment Cell Melanoma Res. 2008; 21:27-38. [PubMed: 18353141]

26. Afaq F, Adhami VM, Mukhtar H. Photochemoprevention of ultraviolet B signaling and photocarcinogenesis. Mutat Res. 2005; 571:153-73. [PubMed: 15748645]

27. Demierre MF, Merlino G. Chemoprevention of melanoma. Curr Oncol Rep. 2004; 6:406-13. [PubMed: 15291986]

28. Lluria-Prevatt M, Morreale J, Gregus J, et al. Effects of perillyl alcohol on melanoma in the TPras mouse model. Cancer Epidemiol Biomarkers Prev. 2002; 11:573-9. [PubMed: 12050099]

29. Manoharan SS, RB, Balakrishnan S. Chemopreventive mechanisms of natural products in oral, mammary and skin carcinogenesis: An overview. The Open Nutraceuticals Journal. 2009; 2:5263.

30. Gupta S, Mukhtar H. Chemoprevention of skin cancer through natural agents. Skin Pharmacol Appl Skin Physiol. 2001; 14:373-85. [PubMed: 11598437]

31. Rajendran P, Ho E, Williams DE, Dashwood RH. Dietary phytochemicals, HDAC inhibition, and DNA damage/repair defects in cancer cells. Clin Epigenetics. 2011; 3:4. [PubMed: 22247744]

32. Nambiar D, Rajamani P, Singh RP. Effects of phytochemicals on ionization radiation-mediated carcinogenesis and cancer therapy. Mutat Res. 2011; 728:139-57. [PubMed: 22030216]

33. Nichols JA, Katiyar SK. Skin photoprotection by natural polyphenols: anti-inflammatory, antioxidant and DNA repair mechanisms. Arch Dermatol Res. 2010; 302:71-83. [PubMed: 19898857]

34. Demierre MF, Sondak VK. Chemoprevention of melanoma: theoretical and practical considerations. Cancer Control. 2005; 12:219-22. [PubMed: 16258492]

35. Demierre MF, Sondak VK. Cutaneous melanoma: pathogenesis and rationale for chemoprevention. Crit Rev Oncol Hematol. 2005; 53:225-39. [PubMed: 15718148]

36. Armstrong WB, Taylor TH, Meyskens FL Jr. Point: Surrogate end point biomarkers are likely to be limited in their usefulness in the development of cancer chemoprevention agents against sporadic cancers. Cancer Epidemiol Biomarkers Prev. 2003; 12:589-92. [PubMed: 12869395]

37. Ming ME. The search for a chemoprevention agent effective against melanoma: considerations and challenges. J Invest Dermatol. 2011; 131:1401-3. [PubMed: 21673707]

38. Satyamoorthy K, Meier F, Hsu MY, Berking C, Herlyn M. Human xenografts, human skin and skin reconstructs for studies in melanoma development and progression. Cancer Metastasis Rev. 1999; 18:401-5. [PubMed: 10721493]

39. Nguyen N, Sharma A, Nguyen N, et al. Melanoma chemoprevention in skin reconstructs and mouse xenografts using isoselenocyanate-4. Cancer Prev Res (Phila). 2011; 4:248-58. [PubMed: 21097713]

40. Chung CY, Madhunapantula SV, Desai D, Amin S, Robertson GP. Melanoma prevention using topical PBISe. Cancer Prev Res (Phila). 2011; 4:935-48. [PubMed: 21367959]

41. Becker JC, Houben R, Schrama D, Voigt H, Ugurel S, Reisfeld RA. Mouse models for melanoma: a personal perspective. Exp Dermatol. 2010; 19:157-64. [PubMed: 19849715] 
42. Dankort D, Curley DP, Cartlidge RA, et al. Braf(V600E) cooperates with Pten loss to induce metastatic melanoma. Nat Genet. 2009; 41:544-52. [PubMed: 19282848]

43. Noonan FP, Dudek J, Merlino G, De Fabo EC. Animal models of melanoma: an HGF/SF transgenic mouse model may facilitate experimental access to UV initiating events. Pigment Cell Res. 2003; 16:16-25. [PubMed: 12519121]

44. Mintz B, Silvers WK. Transgenic mouse model of malignant skin melanoma. Proc Natl Acad Sci U S A. 1993; 90:8817-21. [PubMed: 8415613]

45. Ha L, Noonan FP, De Fabo EC, Merlino G. Animal models of melanoma. J Investig Dermatol Symp Proc. 2005; 10:86-8.

46. Walter RB, Kazianis S. Xiphophorus interspecies hybrids as genetic models of induced neoplasia. ILAR J. 2001; 42:299-321. [PubMed: 11581522]

47. Curiel-Lewandrowski C, Nijsten T, Gomez ML, Hollestein LM, Atkins MB, Stern RS. Long-term use of nonsteroidal anti-inflammatory drugs decreases the risk of cutaneous melanoma: results of a United States case-control study. J Invest Dermatol. 2011; 131:1460-8. [PubMed: 21390049]

48. Bonovas S, Nikolopoulos G, Filioussi K, Peponi E, Bagos P, Sitaras NM. Can statin therapy reduce the risk of melanoma? A meta-analysis of randomized controlled trials. Eur J Epidemiol. 2010; 25:29-35. [PubMed: 19844794]

49. Demierre MF, Higgins PD, Gruber SB, Hawk E, Lippman SM. Statins and cancer prevention. Nat Rev Cancer. 2005; 5:930-42. [PubMed: 16341084]

50. Hippisley-Cox J, Coupland C. Unintended effects of statins in men and women in England and Wales: population based cohort study using the QResearch database. BMJ. 2010; 340:c2197. [PubMed: 20488911]

51. Khosravi-Far R, Cox AD, Kato K, Der CJ. Protein prenylation: key to ras function and cancer intervention? Cell Growth Differ. 1992; 3:461-9. [PubMed: 1419908]

52. Collisson EA, Kleer C, Wu M, et al. Atorvastatin prevents RhoC isoprenylation, invasion, and metastasis in human melanoma cells. Mol Cancer Ther. 2003; 2:941-8. [PubMed: 14578459]

53. Kidera Y, Tsubaki M, Yamazoe Y, et al. Reduction of lung metastasis, cell invasion, and adhesion in mouse melanoma by statin-induced blockade of the Rho/Rho-associated coiled-coil-containing protein kinase pathway. J Exp Clin Cancer Res. 2010; 29:127. [PubMed: 20843370]

54. Feleszko W, Mlynarczuk I, Olszewska D, et al. Lovastatin potentiates antitumor activity of doxorubicin in murine melanoma via an apoptosis-dependent mechanism. Int J Cancer. 2002; 100:111-8. [PubMed: 12115596]

55. Bonovas S, Filioussi K, Tsavaris N, Sitaras NM. Statins and cancer risk: a literature-based metaanalysis and meta-regression analysis of 35 randomized controlled trials. J Clin Oncol. 2006; 24:4808-17. [PubMed: 17001070]

56. Demierre MF. Consideration of statins for chemoprevention of cutaneous melanoma. J Drugs Dermatol. 2005; 4:125-8. [PubMed: 15696998]

57. Kuoppala J, Lamminpaa A, Pukkala E. Statins and cancer: A systematic review and meta-analysis. Eur J Cancer. 2008; 44:2122-32. [PubMed: 18707867]

58. Gupta SC, Prasad S, Kim JH, et al. Multitargeting by curcumin as revealed by molecular interaction studies. Nat Prod Rep. 2011; 28:1937-55. [PubMed: 21979811]

59. Kim JH, Gupta SC, Park B, Yadav VR, Aggarwal BB. Turmeric (Curcuma longa) inhibits inflammatory nuclear factor (NF)-kappaB and NF-kappaB-regulated gene products and induces death receptors leading to suppressed proliferation, induced chemosensitization, and suppressed osteoclastogenesis. Mol Nutr Food Res. 2011

60. Siwak DR, Shishodia S, Aggarwal BB, Kurzrock R. Curcumin-induced antiproliferative and proapoptotic effects in melanoma cells are associated with suppression of IkappaB kinase and nuclear factor kappaB activity and are independent of the B-Raf/mitogen-activated/extracellular signal-regulated protein kinase pathway and the Akt pathway. Cancer. 2005; 104:879-90. [PubMed: 16007726]

61. Chen LX, He YJ, Zhao SZ, et al. Inhibition of tumor growth and vasculogenic mimicry by curcumin through down-regulation of the EphA2/PI3K/MMP pathway in a murine choroidal melanoma model. Cancer Biol Ther. 2011; 11:229-35. [PubMed: 21084858] 
62. Baliga MS, Katiyar SK. Chemoprevention of photocarcinogenesis by selected dietary botanicals. Photochem Photobiol Sci. 2006; 5:243-53. [PubMed: 16465310]

63. Limtrakul P, Anuchapreeda S, Lipigorngoson S, Dunn FW. Inhibition of carcinogen induced c-Haras and c-fos proto-oncogenes expression by dietary curcumin. BMC Cancer. 2001; 1:1. [PubMed: 11231886]

64. Limtrakul P, Lipigorngoson S, Namwong O, Apisariyakul A, Dunn FW. Inhibitory effect of dietary curcumin on skin carcinogenesis in mice. Cancer Lett. 1997; 116:197-203. [PubMed: 9215864]

65. Mimeault M, Batra SK. Potential applications of curcumin and its novel synthetic analogs and nanotechnology-based formulations in cancer prevention and therapy. Chin Med. 2011; 6:31. [PubMed: 21859497]

66. Marin YE, Wall BA, Wang S, et al. Curcumin downregulates the constitutive activity of NFkappaB and induces apoptosis in novel mouse melanoma cells. Melanoma Res. 2007; 17:274-83. [PubMed: 17885582]

67. Bush JA, Cheung KJ Jr, Li G. Curcumin induces apoptosis in human melanoma cells through a Fas receptor/caspase-8 pathway independent of p53. Exp Cell Res. 2001; 271:305-14. [PubMed: 11716543]

68. Huang MT, Ma W, Yen P, et al. Inhibitory effects of topical application of low doses of curcumin on 12-O-tetradecanoylphorbol-13-acetate-induced tumor promotion and oxidized DNA bases in mouse epidermis. Carcinogenesis. 1997; 18:83-8. [PubMed: 9054592]

69. Kakar SS, Roy D. Curcumin inhibits TPA induced expression of c-fos, c-jun and c-myc protooncogenes messenger RNAs in mouse skin. Cancer Lett. 1994; 87:85-9. [PubMed: 7954373]

70. Menon LG, Kuttan R, Kuttan G. Inhibition of lung metastasis in mice induced by B16F10 melanoma cells by polyphenolic compounds. Cancer Lett. 1995; 95:221-5. [PubMed: 7656234]

71. Ray S, Chattopadhyay N, Mitra A, Siddiqi M, Chatterjee A. Curcumin exhibits antimetastatic properties by modulating integrin receptors, collagenase activity, and expression of Nm23 and Ecadherin. J Environ Pathol Toxicol Oncol. 2003; 22:49-58. [PubMed: 12678405]

72. Banerji A, Chakrabarti J, Mitra A, Chatterjee A. Effect of curcumin on gelatinase A (MMP-2) activity in B16F10 melanoma cells. Cancer Lett. 2004; 211:235-42. [PubMed: 15219947]

73. Heng MC. Curcumin targeted signaling pathways: basis for anti-photoaging and anti-carcinogenic therapy. Int J Dermatol. 2010; 49:608-22. [PubMed: 20618464]

74. Autier P, Dore JF, Eggermont AM, Coebergh JW. Epidemiological evidence that UVA radiation is involved in the genesis of cutaneous melanoma. Curr Opin Oncol. 2011; 23:189-96. [PubMed: 21192263]

75. Sa G, Das T. Anti cancer effects of curcumin: cycle of life and death. Cell Div. 2008; 3:14. [PubMed: 18834508]

76. Anand P, Sundaram C, Jhurani S, Kunnumakkara AB, Aggarwal BB. Curcumin and cancer: an "old-age" disease with an "age-old" solution. Cancer Lett. 2008; 267:133-64. [PubMed: 18462866]

77. Anand P, Thomas SG, Kunnumakkara AB, et al. Biological activities of curcumin and its analogues (Congeners) made by man and Mother Nature. Biochem Pharmacol. 2008; 76:1590_ 611. [PubMed: 18775680]

78. Langone P, Debata PR, Dolai S, et al. Coupling to a cancer cell-specific antibody potentiates tumoricidal properties of curcumin. Int J Cancer. 2011

79. Niles RM, McFarland M, Weimer MB, Redkar A, Fu YM, Meadows GG. Resveratrol is a potent inducer of apoptosis in human melanoma cells. Cancer Lett. 2003; 190:157-63. [PubMed: 12565170]

80. Aggarwal BB, Bhardwaj A, Aggarwal RS, Seeram NP, Shishodia S, Takada Y. Role of resveratrol in prevention and therapy of cancer: preclinical and clinical studies. Anticancer Res. 2004; 24:2783-840. [PubMed: 15517885]

81. Back JH, Zhu Y, Calabro A, et al. Resveratrol-Mediated Downregulation of Rictor Attenuates Autophagic Process and Suppresses UV-Induced Skin Carcinogenesis(dagger). Photochem Photobiol. 2012 
82. Bhat KP, Pezzuto JM. Cancer chemopreventive activity of resveratrol. Ann N Y Acad Sci. 2002; 957:210-29. [PubMed: 12074974]

83. Aziz MH, Afaq F, Ahmad N. Prevention of ultraviolet-B radiation damage by resveratrol in mouse skin is mediated via modulation in survivin. Photochem Photobiol. 2005; 81:25-31. [PubMed: 15469386]

84. Aziz MH, Reagan-Shaw S, Wu J, Longley BJ, Ahmad N. Chemoprevention of skin cancer by grape constituent resveratrol: relevance to human disease? FASEB J. 2005; 19:1193-5. [PubMed: 15837718]

85. Calamini B, Ratia K, Malkowski MG, et al. Pleiotropic mechanisms facilitated by resveratrol and its metabolites. Biochem J. 2010; 429:273-82. [PubMed: 20450491]

86. Holthoff JH, Woodling KA, Doerge DR, Burns ST, Hinson JA, Mayeux PR. Resveratrol, a dietary polyphenolic phytoalexin, is a functional scavenger of peroxynitrite. Biochem Pharmacol. 2010; 80:1260-5. [PubMed: 20599800]

87. Kim KH, Back JH, Zhu Y, et al. Resveratrol targets transforming growth factor-beta2 signaling to block UV-induced tumor progression. J Invest Dermatol. 2011; 131:195-202. [PubMed: 20720562]

88. Walle T. Bioavailability of resveratrol. Ann N Y Acad Sci. 2011; 1215:9-15. [PubMed: 21261636]

89. Patel KR, Scott E, Brown VA, Gescher AJ, Steward WP, Brown K. Clinical trials of resveratrol. Ann N Y Acad Sci. 2011; 1215:161-9. [PubMed: 21261655]

90. Miksits M, Wlcek K, Svoboda M, et al. Antitumor activity of resveratrol and its sulfated metabolites against human breast cancer cells. Planta Med. 2009; 75:1227-30. [PubMed: 19350482]

91. Niles RM, Cook CP, Meadows GG, Fu YM, McLaughlin JL, Rankin GO. Resveratrol is rapidly metabolized in athymic (nu/nu) mice and does not inhibit human melanoma xenograft tumor growth. J Nutr. 2006; 136:2542-6. [PubMed: 16988123]

92. Szekeres T, Saiko P, Fritzer-Szekeres M, Djavan B, Jager W. Chemopreventive effects of resveratrol and resveratrol derivatives. Ann N Y Acad Sci. 2011; 1215:89-95. [PubMed: 21261645]

93. Szekeres T, Fritzer-Szekeres M, Saiko P, Jager W. Resveratrol and resveratrol analogues-structure-activity relationship. Pharm Res. 2010; 27:1042-8. [PubMed: 20232118]

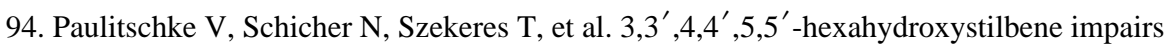
melanoma progression in a metastatic mouse model. J Invest Dermatol. 2010; 130:1668-79. [PubMed: 19956188]

95. Afaq F, Katiyar SK. Polyphenols: skin photoprotection and inhibition of photocarcinogenesis. Mini Rev Med Chem. 2011; 11:1200-15. [PubMed: 22070679]

96. Katiyar SK, Mantena SK, Meeran SM. Silymarin protects epidermal keratinocytes from ultraviolet radiation-induced apoptosis and DNA damage by nucleotide excision repair mechanism. PLoS One. 2011; 6:e21410. [PubMed: 21731736]

97. Li LH, Wu LJ, Zhou B, et al. Silymarin prevents UV irradiation-induced A375-S2 cell apoptosis. Biol Pharm Bull. 2004; 27:1031-6. [PubMed: 15256735]

98. Vaid M, Katiyar SK. Molecular mechanisms of inhibition of photocarcinogenesis by silymarin, a phytochemical from milk thistle (Silybum marianum L. Gaertn) (Review). Int J Oncol. 2010; 36:1053-60. [PubMed: 20372777]

99. Li LH, Wu LJ, Tashiro SI, Onodera S, Uchiumi F, Ikejima T. The roles of Akt and MAPK family members in silymarin's protection against UV-induced A375-S2 cell apoptosis. Int Immunopharmacol. 2006; 6:190-7. [PubMed: 16399623]

100. Vaid M, Prasad R, Sun Q, Katiyar SK. Silymarin targets beta-catenin signaling in blocking migration/invasion of human melanoma cells. PLoS One. 2011; 6:e23000. [PubMed: 21829575]

101. Katiyar SK. Silymarin and skin cancer prevention: anti-inflammatory, antioxidant and immunomodulatory effects (Review). Int J Oncol. 2005; 26:169-76. [PubMed: 15586237]

102. Meeran SM, Katiyar S, Elmets CA, Katiyar SK. Silymarin inhibits UV radiation-induced immunosuppression through augmentation of interleukin-12 in mice. Mol Cancer Ther. 2006; 5:1660-8. [PubMed: 16891451] 
103. Katiyar S, Elmets CA, Katiyar SK. Green tea and skin cancer: photoimmunology, angiogenesis and DNA repair. J Nutr Biochem. 2007; 18:287-96. [PubMed: 17049833]

104. Barthelman M, Bair WB 3rd, Stickland KK, et al. (-)-Epigallocatechin-3-gallate inhibition of ultraviolet B-induced AP-1 activity. Carcinogenesis. 1998; 19:2201-4. [PubMed: 9886579]

105. Mittal A, Piyathilake C, Hara Y, Katiyar SK. Exceptionally high protection of photocarcinogenesis by topical application of (--)-epigallocatechin-3-gallate in hydrophilic cream in SKH-1 hairless mouse model: relationship to inhibition of UVB-induced global DNA hypomethylation. Neoplasia. 2003; 5:555-65. [PubMed: 14965448]

106. Nihal M, Ahmad N, Mukhtar H, Wood GS. Anti-proliferative and proapoptotic effects of (-)epigallocatechin-3-gallate on human melanoma: possible implications for the chemoprevention of melanoma. Int J Cancer. 2005; 114:513-21. [PubMed: 15609335]

107. Lu YP, Lou YR, Xie JG, et al. Topical applications of caffeine or (-)-epigallocatechin gallate (EGCG) inhibit carcinogenesis and selectively increase apoptosis in UVB-induced skin tumors in mice. Proc Natl Acad Sci U S A. 2002; 99:12455-60. [PubMed: 12205293]

108. Taniguchi S, Fujiki H, Kobayashi H, et al. Effect of (-)-epigallocatechin gallate, the main constituent of green tea, on lung metastasis with mouse B16 melanoma cell lines. Cancer Lett. 1992; 65:51-4. [PubMed: 1511409]

109. Konta L, Szaraz P, Magyar JE, et al. Inhibition of glycoprotein synthesis in the endoplasmic reticulum as a novel anticancer mechanism of (-)-epigallocatechin-3-gallate. Biofactors. 2011; 37:468-76. [PubMed: 22162335]

110. Liu JD, Chen SH, Lin CL, Tsai SH, Liang YC. Inhibition of melanoma growth and metastasis by combination with (-)-epigallocatechin-3-gallate and dacarbazine in mice. J Cell Biochem. 2001; 83:631-42. [PubMed: 11746506]

111. Brozmanova J, Manikova D, Vlckova V, Chovanec M. Selenium: a double-edged sword for defense and offence in cancer. Arch Toxicol. 2010; 84:919-38. [PubMed: 20871980]

112. Nguyen N, Sharma A, Sharma AK, et al. Melanoma chemoprevention in skin reconstructs and mouse xenografts using isoselenocyanate-4. Cancer Prev Res (Phila). 2011; 4:248-58. [PubMed: 21097713]

113. Clark LC, Combs GF Jr, Turnbull BW, et al. Effects of selenium supplementation for cancer prevention in patients with carcinoma of the skin. A randomized controlled trial. Nutritional Prevention of Cancer Study Group. Jama. 1996; 276:1957-63. [PubMed: 8971064]

114. Lippman SM, Klein EA, Goodman PJ, et al. Effect of selenium and vitamin E on risk of prostate cancer and other cancers: the Selenium and Vitamin E Cancer Prevention Trial (SELECT). Jama. 2009; 301:39-51. [PubMed: 19066370]

115. Duffield-Lillico AJ, Shureiqi I, Lippman SM. Can selenium prevent colorectal cancer? A signpost from epidemiology. J Natl Cancer Inst. 2004; 96:1645-7. [PubMed: 15547171]

116. Allen NE, Appleby PN, Roddam AW, et al. Plasma selenium concentration and prostate cancer risk: results from the European Prospective Investigation into Cancer and Nutrition (EPIC). Am J Clin Nutr. 2008; 88:1567-75. [PubMed: 19064517]

117. Duffield-Lillico AJ, Reid ME, Turnbull BW, et al. Baseline characteristics and the effect of selenium supplementation on cancer incidence in a randomized clinical trial: a summary report of the Nutritional Prevention of Cancer Trial. Cancer Epidemiol Biomarkers Prev. 2002; 11:630-9. [PubMed: 12101110]

118. Dennert G, Zwahlen M, Brinkman M, Vinceti M, Zeegers MP, Horneber M. Selenium for preventing cancer. Sao Paulo Med J. 2012; 130:67.

119. Dennert G, Zwahlen M, Brinkman M, Vinceti M, Zeegers MP, Horneber M. Selenium for preventing cancer. Cochrane Database Syst Rev. 2011:CD005195. [PubMed: 21563143]

120. Madhunapantula SV, Desai D, Sharma A, Huh S, Amin S, Robertson GP. PBIse, a novel selenium containing drug for the treatment of malignant melanoma. Mol Cancer Ther. 2008; 7:1297-308. [PubMed: 18483317]

121. Sharma A, Sharma AK, Madhunapantula SV, et al. Targeting Akt3 Signaling in Malignant Melanoma Using Isoselenocyanates. Clin Cancer Res. 2009 
122. Li D, Graef GL, Yee JA, Yan L. Dietary supplementation with high-selenium soy protein reduces pulmonary metastasis of melanoma cells in mice. J Nutr. 2004; 134:1536-40. [PubMed: 15173425]

123. Yan L, Yee JA, Li D, McGuire MH, Graef GL. Dietary supplementation of selenomethionine reduces metastasis of melanoma cells in mice. Anticancer Res. 1999; 19:1337-42. [PubMed: 10368696]

124. Tanaka T, Kohno H, Murakami M, Kagami S, El-Bayoumy K. Suppressing effects of dietary supplementation of the organoselenium 1,4-phenylenebis(methylene)selenocyanate and the Citrus antioxidant auraptene on lung metastasis of melanoma cells in mice. Cancer Res. 2000; 60:3713-6. [PubMed: 10919638]

125. Sharma AK, Sharma A, Desai D, et al. Synthesis and anticancer activity comparison of phenylalkyl isoselenocyanates with corresponding naturally occurring and synthetic isothiocyanates. J Med Chem. 2008; 51:7820-6. [PubMed: 19053750]

126. Desai D, Madhunapantula SV, Gowdahalli K, et al. Synthesis and characterization of a novel iNOS/Akt inhibitor Se,Se' -1,4-phenylenebis(1,2-ethanediyl)bisisoselenourea (PBISe)--against colon cancer. Bioorg Med Chem Lett. 2010; 20:2038-43. [PubMed: 20153642]

127. Crampsie MA, Jones N, Das A, et al. Phenylbutyl isoselenocyanate modulates phase I and II enzymes and inhibits 4-(methylnitrosamino)-1-(3-pyridyl)- 1-butanone-induced DNA adducts in mice. Cancer Prev Res (Phila). 2011; 4:1884-94. [PubMed: 21795424]

128. Sharma AK, Kline CL, Berg A, Amin S, Irby RB. The Akt inhibitor ISC-4 activates prostate apoptosis response protein- 4 and reduces colon tumor growth in a nude mouse model. Clin Cancer Res. 2011; 17:4474-83. [PubMed: 21555373]

129. Stahl JM, Sharma A, Cheung M, et al. Deregulated Akt3 activity promotes development of malignant melanoma. Cancer Res. 2004; 64:7002-10. [PubMed: 15466193]

130. Ekmekcioglu S, Ellerhorst JA, Prieto VG, Johnson MM, Broemeling LD, Grimm EA. Tumor iNOS predicts poor survival for stage III melanoma patients. Int J Cancer. 2006; 119:861-6. [PubMed: 16557582]

131. Sikora AG, Gelbard A, Davies MA, et al. Targeted inhibition of inducible nitric oxide synthase inhibits growth of human melanoma in vivo and synergizes with chemotherapy. Clin Cancer Res. 2010; 16:1834-44. [PubMed: 20215556]

132. Cheung M, Sharma A, Madhunapantula SV, Robertson GP. Akt3 and mutant V600E B-Raf cooperate to promote early melanoma development. Cancer Res. 2008; 68:3429-39. [PubMed: 18451171]

133. Friedman ES, LaNatra N, Stiller MJ. NSAIDs in dermatologic therapy: review and preview. J Cutan Med Surg. 2002; 6:449-59. [PubMed: 12202973]

134. Jeter JM, Bonner JD, Johnson TM, Gruber SB. Nonsteroidal anti-inflammatory drugs and risk of melanoma. J Skin Cancer. 2011; 2011:598571. [PubMed: 21773038]

135. Denkert C, Kobel M, Berger S, et al. Expression of cyclooxygenase 2 in human malignant melanoma. Cancer Res. 2001; 61:303-8. [PubMed: 11196178]

136. Joosse A, Koomen ER, Casparie MK, Herings RM, Guchelaar HJ, Nijsten T. Non-steroidal antiinflammatory drugs and melanoma risk: large Dutch population-based case-control study. J Invest Dermatol. 2009; 129:2620-7. [PubMed: 19587697]

137. Bard S, Kirsner RS. Do nonsteroidal anti-inflammatory drugs prevent melanoma? J Invest Dermatol. 2011; 131:1394. [PubMed: 21673704]

138. Asgari MM, Maruti SS, White E. A large cohort study of nonsteroidal anti-inflammatory drug use and melanoma incidence. J Natl Cancer Inst. 2008; 100:967-71. [PubMed: 18577752]

139. Park IS, Jo JR, Hong H, et al. Aspirin induces apoptosis in YD-8 human oral squamous carcinoma cells through activation of caspases, down-regulation of Mcl-1, and inactivation of ERK-1/2 and AKT. Toxicol In Vitro. 2010; 24:713-20. [PubMed: 20116423]

140. Zhou XM, Wong BC, Fan XM, et al. Non-steroidal anti-inflammatory drugs induce apoptosis in gastric cancer cells through up-regulation of bax and bak. Carcinogenesis. 2001; 22:1393-7. [PubMed: 11532860]

141. Stahl W, Sies H. Photoprotection by dietary carotenoids: Concept, mechanisms, evidence and future development. Mol Nutr Food Res. 2011 
142. Guruvayoorappan C, Kuttan G. Beta-carotene inhibits tumor-specific angiogenesis by altering the cytokine profile and inhibits the nuclear translocation of transcription factors in B16F-10 melanoma cells. Integr Cancer Ther. 2007; 6:258-70. [PubMed: 17761639]

143. Bodzioch M, Dembinska-Kiec A, Hartwich J, et al. The microarray expression analysis identifies BAX as a mediator of beta-carotene effects on apoptosis. Nutr Cancer. 2005; 51:226-35. [PubMed: 15860445]

144. Frieling UM, Schaumberg DA, Kupper TS, Muntwyler J, Hennekens CH. A randomized, 12-year primary-prevention trial of beta carotene supplementation for nonmelanoma skin cancer in the physician's health study. Arch Dermatol. 2000; 136:179-84. [PubMed: 10677093]

145. Green A, Williams G, Neale R, et al. Daily sunscreen application and betacarotene supplementation in prevention of basal-cell and squamous-cell carcinomas of the skin: a randomised controlled trial. Lancet. 1999; 354:723-9. [PubMed: 10475183]

146. Wilson KS. Clinical activity of celecoxib in metastatic malignant melanoma. Cancer Invest. 2006; 24:740-6. [PubMed: 17162556]

147. Becker MR, Siegelin MD, Rompel R, Enk AH, Gaiser T. COX-2 expression in malignant melanoma: a novel prognostic marker? Melanoma Res. 2009; 19:8-16. [PubMed: 19430402]

148. Khan Z, Khan N, Tiwari RP, Sah NK, Prasad GB, Bisen PS. Biology of Cox-2: an application in cancer therapeutics. Curr Drug Targets. 2011; 12:1082-93. [PubMed: 21443470]

149. Fitzpatrick FA. Cyclooxygenase enzymes: regulation and function. Curr Pharm Des. 2004; 10:577-88. [PubMed: 14965321]

150. Flower RJ. The development of COX2 inhibitors. Nat Rev Drug Discov. 2003; 2:179-91. [PubMed: 12612644]

151. Rundhaug JE, Fischer SM. Cyclo-oxygenase-2 plays a critical role in UV-induced skin carcinogenesis. Photochem Photobiol. 2008; 84:322-9. [PubMed: 18194346]

152. Buckman SY, Gresham A, Hale P, et al. COX-2 expression is induced by UVB exposure in human skin: implications for the development of skin cancer. Carcinogenesis. 1998; 19:723-9. [PubMed: 9635856]

153. Johnson GE, Ivanov VN, Hei TK. Radiosensitization of melanoma cells through combined inhibition of protein regulators of cell survival. Apoptosis. 2008; 13:790-802. [PubMed: 18454317]

154. Elmets CA, Viner JL, Pentland AP, et al. Chemoprevention of nonmelanoma skin cancer with celecoxib: a randomized, double-blind, placebo-controlled trial. J Natl Cancer Inst. 2010; 102:1835-44. [PubMed: 21115882]

155. Wilson KS. Cyclooxygenase-2 inhibition and regression of metastatic melanoma. Melanoma Res. 2006; 16:465. [PubMed: 17013098]

156. Kim HS, Kim MJ, Kim EJ, Yang Y, Lee MS, Lim JS. Berberine-induced AMPK activation inhibits the metastatic potential of melanoma cells via reduction of ERK activity and COX-2 protein expression. Biochem Pharmacol. 2012; 83:385-94. [PubMed: 22120676]

157. Wilgus TA, Breza TS Jr, Tober KL, Oberyszyn TM. Treatment with 5-fluorouracil and celecoxib displays synergistic regression of ultraviolet light B-induced skin tumors. J Invest Dermatol. 2004; 122:1488-94. [PubMed: 15175041]

158. Sunkara PS, Rosenberger AL. Antimetastatic activity of DL-alpha-difluoromethylornithine, an inhibitor of polyamine biosynthesis, in mice. Cancer Res. 1987; 47:933-5. [PubMed: 3100031]

159. Kubota S, Ohsawa N, Takaku F. Effects of DL-alpha-difluoromethylornithine on the growth and metastasis of B16 melanoma in vivo. Int J Cancer. 1987; 39:244-7. [PubMed: 3100460]

160. Croghan MK, Booth A, Meyskens FL Jr. A phase I trial of recombinant interferon-alpha and alpha-difluoromethylornithine in metastatic melanoma. J Biol Response Mod. 1988; 7:409-15. [PubMed: 3139843]

161. Sunkara PS, Prakash NJ, Rosenberger AL, Hagan AC, Lachmann PJ, Mayer GD. Potentiation of antitumor and antimetastatic activities of alpha-difluoromethylornithine by interferon inducers. Cancer Res. 1984; 44:2799-802. [PubMed: 6426786]

162. Meyskens FL, Kingsley EM, Glattke T, Loescher L, Booth A. A phase II study of alphadifluoromethylornithine (DFMO) for the treatment of metastatic melanoma. Invest New Drugs. 1986; 4:257-62. [PubMed: 3102397] 
163. Sunkara PS, Bowlin TL, Rosenberger AL, Fleischmann WR Jr. Effect of murine alpha-, beta-, and gamma-interferons in combination with alpha-difluoromethylornithine, an inhibitor of polyamine biosynthesis, on the tumor growth and metastasis of B16 melanoma and Lewis lung carcinoma in mice. J Biol Response Mod. 1989; 8:170-9. [PubMed: 2499664]

164. Burnett ME, Wang SQ. Current sunscreen controversies: a critical review. Photodermatol Photoimmunol Photomed. 2011; 27:58-67. [PubMed: 21392107]

165. Drolet BA, Connor MJ. Sunscreens and the prevention of ultraviolet radiation-induced skin cancer. J Dermatol Surg Oncol. 1992; 18:571-6. [PubMed: 1624630]

166. Weinstock MA. Do sunscreens increase or decrease melanoma risk: an epidemiologic evaluation. J Investig Dermatol Symp Proc. 1999; 4:97-100.

167. Klug HL, Tooze JA, Graff-Cherry C, et al. Sunscreen prevention of melanoma in man and mouse. Pigment Cell Melanoma Res. 2010; 23:835-7. [PubMed: 20726949]

168. Wolf P, Donawho CK, Kripke ML. Effect of sunscreens on UV radiation-induced enhancement of melanoma growth in mice. J Natl Cancer Inst. 1994; 86:99-105. [PubMed: 8271307]

169. Huncharek M, Kupelnick B. Use of topical sunscreens and the risk of malignant melanoma: a meta-analysis of 9067 patients from 11 case-control studies. Am J Public Health. 2002; 92:11737. [PubMed: 12084704]

170. Dennis LK, Beane Freeman LE, VanBeek MJ. Sunscreen use and the risk for melanoma: a quantitative review. Ann Intern Med. 2003; 139:966-78. [PubMed: 14678916]

171. Antoniou C, Kosmadaki MG, Stratigos AJ, Katsambas AD. Sunscreens--what's important to know. J Eur Acad Dermatol Venereol. 2008; 22:1110-8. [PubMed: 18482317]

172. Gorham ED, Mohr SB, Garland CF, Chaplin G, Garland FC. Do sunscreens increase risk of melanoma in populations residing at higher latitudes? Ann Epidemiol. 2007; 17:956-63. [PubMed: 18022535]

173. Azizi E, Iscovich J, Pavlotsky F, et al. Use of sunscreen is linked with elevated naevi counts in Israeli school children and adolescents. Melanoma Res. 2000; 10:491-8. [PubMed: 11095411]

174. Holly EA, Aston DA, Cress RD, Ahn DK, Kristiansen JJ. Cutaneous melanoma in women. I. Exposure to sunlight, ability to tan, and other risk factors related to ultraviolet light. Am J Epidemiol. 1995; 141:923-33. [PubMed: 7741122]

175. Holly EA, Aston DA, Cress RD, Ahn DK, Kristiansen JJ. Cutaneous melanoma in women. II. Phenotypic characteristics and other host-related factors. Am J Epidemiol. 1995; 141:934-42. [PubMed: 7741123]

176. Holly EA, Cress RD, Ahn DK. Cutaneous melanoma in women. III. Reproductive factors and oral contraceptive use. Am J Epidemiol. 1995; 141:943-50. [PubMed: 7741124]

177. Naylor MF, Boyd A, Smith DW, Cameron GS, Hubbard D, Neldner KH. High sun protection factor sunscreens in the suppression of actinic neoplasia. Arch Dermatol. 1995; 131:170-5. [PubMed: 7857113]

178. van der Pols JC, Williams GM, Pandeya N, Logan V, Green AC. Prolonged prevention of squamous cell carcinoma of the skin by regular sunscreen use. Cancer Epidemiol Biomarkers Prev. 2006; 15:2546-8. [PubMed: 17132769]

179. Autier P, Dore JF, Schifflers E, et al. Melanoma and use of sunscreens: an Eortc case-control study in Germany, Belgium and France. The EORTC Melanoma Cooperative Group. Int J Cancer. 1995; 61:749-55. [PubMed: 7790106]

180. Pisha E, Chai H, Lee IS, et al. Discovery of betulinic acid as a selective inhibitor of human melanoma that functions by induction of apoptosis. Nat Med. 1995; 1:1046-51. [PubMed: 7489361]

181. Cichewicz RH, Kouzi SA. Chemistry, biological activity, and chemotherapeutic potential of betulinic acid for the prevention and treatment of cancer and HIV infection. Med Res Rev. 2004; 24:90-114. [PubMed: 14595673]

182. Fulda S, Friesen C, Los M, et al. Betulinic acid triggers CD95 (APO-1/Fas)- and p53-independent apoptosis via activation of caspases in neuroectodermal tumors. Cancer Res. 1997; 57:4956-64. [PubMed: 9354463]

183. Mullauer FB, Kessler JH, Medema JP. Betulinic acid, a natural compound with potent anticancer effects. Anticancer Drugs. 2010; 21:215-27. [PubMed: 20075711] 
184. Surowiak P, Drag M, Materna V, Dietel M, Lage H. Betulinic acid exhibits stronger cytotoxic activity on the normal melanocyte NHEM-neo cell line than on drug-resistant and drug-sensitive MeWo melanoma cell lines. Mol Med Report. 2009; 2:543-8.

185. Struh CM, Jager S, Schempp CM, Scheffler A, Martin SF. A Novel Triterpene Extract from Mistletoe Induces Rapid Apoptosis in Murine B16.F10 Melanoma Cells. Phytother Res. 2012

186. Galgon T, Wohlrab W, Drager B. Betulinic acid induces apoptosis in skin cancer cells and differentiation in normal human keratinocytes. Exp Dermatol. 2005; 14:736-43. [PubMed: 16176281]

187. Qiu L, Wang Q, Di W, et al. Transient activation of EGFR/AKT cell survival pathway and expression of survivin contribute to reduced sensitivity of human melanoma cells to betulinic acid. Int J Oncol. 2005; 27:823-30. [PubMed: 16077934]

188. Rieber M, Rieber MS. Signalling responses linked to betulinic acid-induced apoptosis are antagonized by MEK inhibitor U0126 in adherent or 3D spheroid melanoma irrespective of p53 status. Int J Cancer. 2006; 118:1135-43. [PubMed: 16152620]

189. Rieber M, Strasberg-Rieber M. Induction of p53 and melanoma cell death is reciprocal with down-regulation of E2F, cyclin D1 and pRB. Int J Cancer. 1998; 76:757-60. [PubMed: 9610736]

190. Rieber M, Strasberg Rieber M. Induction of p53 without increase in p21WAF1 in betulinic acidmediated cell death is preferential for human metastatic melanoma. DNA Cell Biol. 1998; 17:399-406. [PubMed: 9628583]

191. Reichrath J, Rech M, Moeini M, Meese E, Tilgen W, Seifert M. In vitro comparison of the vitamin D endocrine system in 1,25(OH)2D3-responsive and -resistant melanoma cells. Cancer Biol Ther. 2007; 6:48-55. [PubMed: 17172823]

192. Eisman JA, Barkla DH, Tutton PJ. Suppression of in vivo growth of human cancer solid tumor xenografts by 1,25-dihydroxyvitamin D3. Cancer Res. 1987; 47:21-5. [PubMed: 3024816]

193. Millen AE, Tucker MA, Hartge P, et al. Diet and melanoma in a case-control study. Cancer Epidemiol Biomarkers Prev. 2004; 13:1042-51. [PubMed: 15184262]

194. Weinstock MA, Stampfer MJ, Lew RA, Willett WC, Sober AJ. Case-control study of melanoma and dietary vitamin D: implications for advocacy of sun protection and sunscreen use. J Invest Dermatol. 1992; 98:809-11. [PubMed: 1569330] 


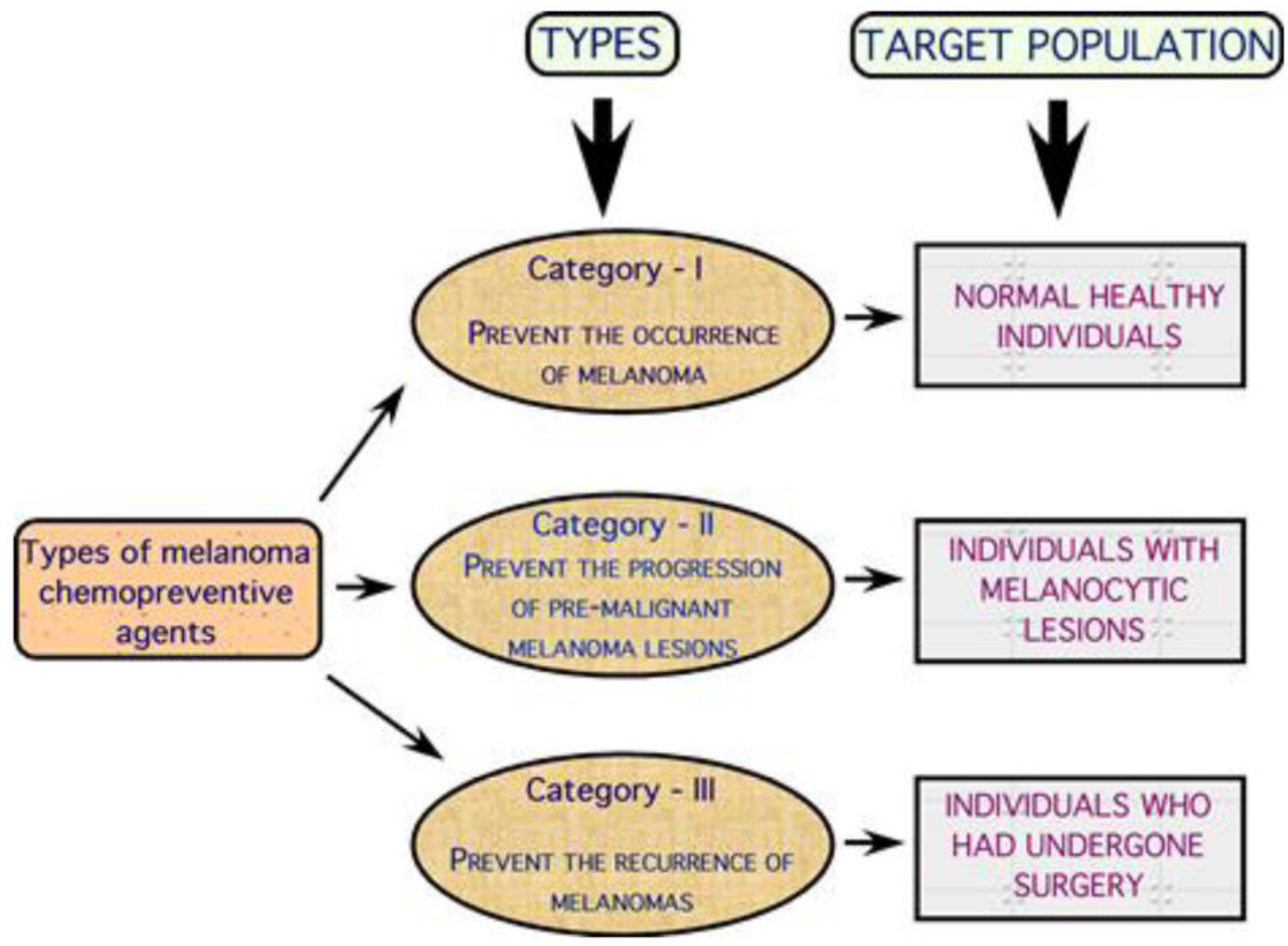

Figure 1.

Types of chemopreventive agents used for preventing melanomas. Chemopreventive agents have been classified based on whether they prevent the occurrence of melanomas in normal healthy individuals (Category - I), or prevent the progression of already existing melanomas (Category - II), or inhibit the recurrence of melanomas after a surgical treatment. 
In vitro experimental models

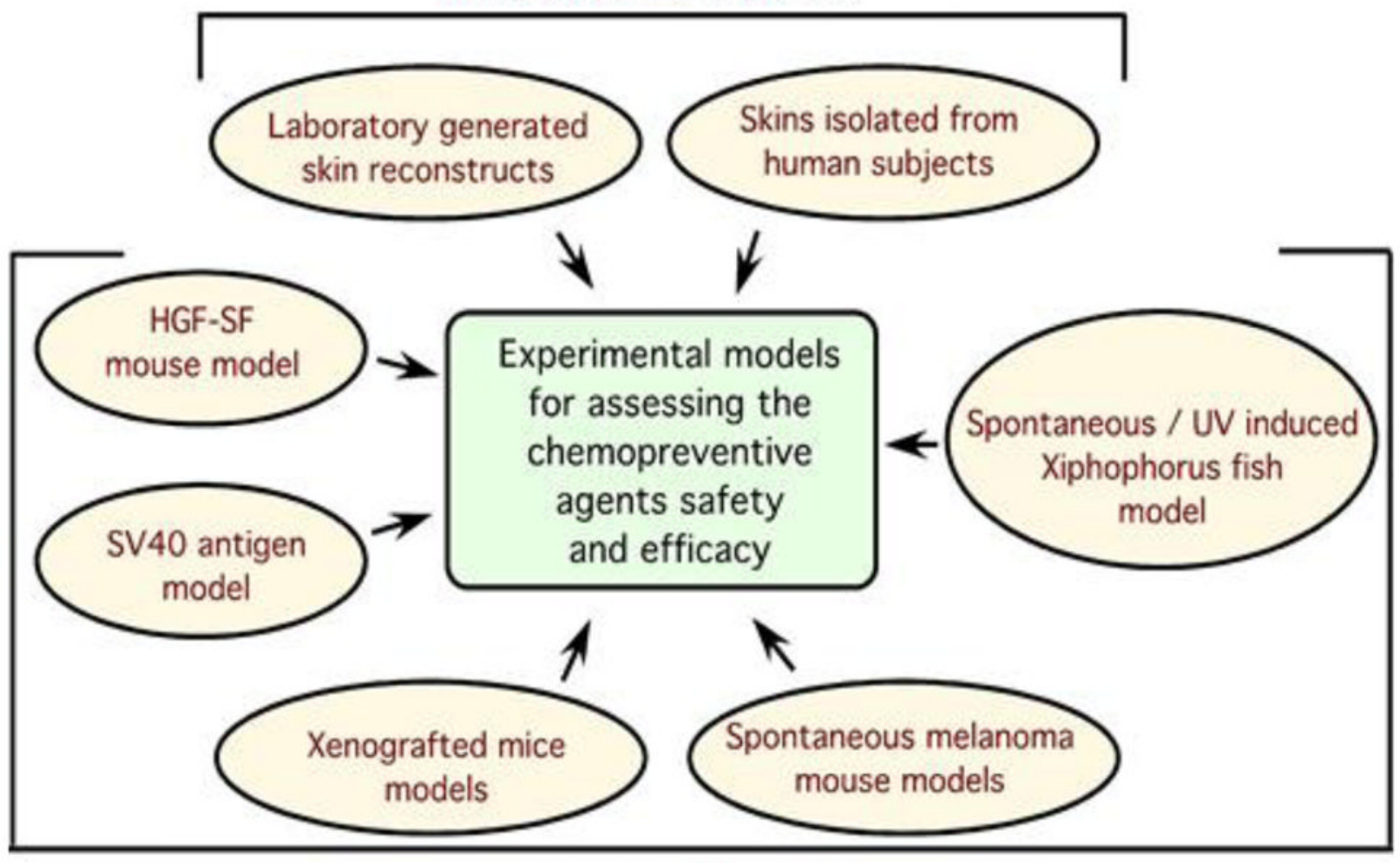

In vivo animal models

Figure 2.

In vitro and In vivo models for testing the efficacy of melanoma preventing agents. Several in vitro and in vivo models have been developed and tested for suitability to evaluate the safety and efficacy of a particular chemopreventive agent. Although the in vitro skin reconstruct model is a good representative of human skins it is not an exact replica of the in vivo situation, hence several in vivo models also used for chemopreventive agents efficacy and safety testing. Xenografted and spontaneous mouse models have been utilized for chemoprevention studies. Additional models include transgenic mouse models and fish models of melanoma 


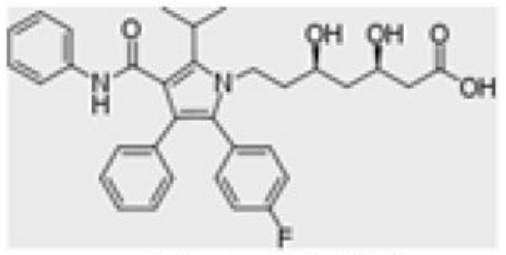

Astrovastatin (52)

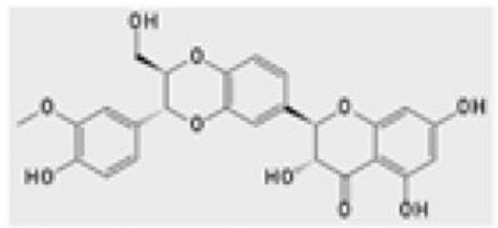

Sllbinin (A constituent of Silymarin) $(95,96)$

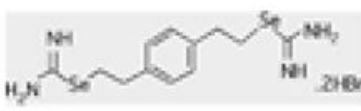

PBIŚe

$(120,126)$

Betulinic acid (180)

Figure 3.<smiles>COc1cc(/C=C/C(=O)CC(=O)/C=C/c2ccc(O)c(OC)c2)ccc1O</smiles>

Curcumin (58, 59)

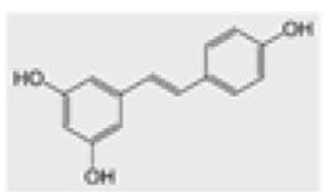

Resweratrol (79)<smiles>O=C(OC1Cc2c(O)cc(O)cc2OC1c1cc(O)c(O)c(O)c1)c1cc(O)c(O)c(O)c1</smiles><smiles>C[Se]CCC(N)C(=O)O</smiles><smiles>C#CCc1ccc(COC)cc1</smiles><smiles>CCCCCc1ccccc1</smiles>

ISC-4

$(121,125)$

EGCG (103-105) Selenomethionine p-XSC (124) (114-116)
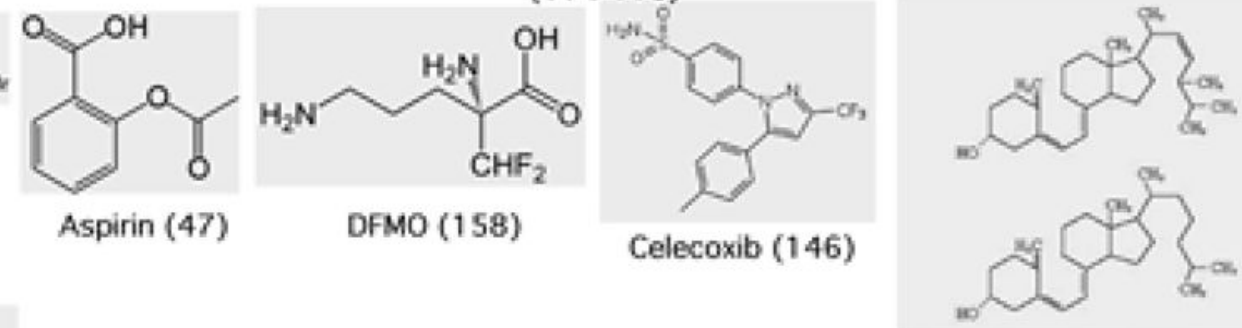

Vitamin D2 and D3 $(191,192)$

\section{Beta carotene (141)}

Structures of reported chemopreventive agents tested against melanoma. Chemopreventive agents that have been tested using in vitro and in vivo models for preventing melanoma are shown. For additional information refer the citations listed in parenthesis. 